Risk Factors for Infectious Complications after Open Fractures; A Systematic Review and Meta-analysis

Kirsten Kortram MD PhD ${ }^{1}$, Hans Bezstarosti MD ${ }^{1}$, Willem-Jan Metsemakers MD PhD², Michael J. Raschke, MD PhD ${ }^{3}$, Esther M.M. Van Lieshout PhD ${ }^{1}$, Michael H.J. Verhofstad MD PhD ${ }^{1 \$}$

1. Trauma Research Unit Department of Surgery, Erasmus MC, University Medical Center Rotterdam, PO Box 2040, 3000CA Rotterdam, The Netherlands

2. Department of Trauma Surgery, University Hospitals Leuven, Herestraat 49, B-3000 Leuven, Belgium

3. Department of Trauma Surgery, University Hospital Münster, Waldeyerstrasse 1, 48149, Münster, Germany

\$ Corresponding author: Michael H.J. Verhofstad, MD PhD Erasmus MC, University Medical Center Rotterdam Trauma Research Unit Department of Surgery, Room H820 P.O. Box 2040 3000 CA Rotterdam, The Netherlands Telephone number: +31 107031050 Fax number: +31 107032396 


\section{Risk Factors for Infectious Complications after Open Fractures; A Systematic Review and Meta-analysis}

\section{Abstract}

Purpose To identify risk factors for the development of infection after open fracture fixation.

Methods A comprehensive search in all scientific literature of the last 30 years was performed in order to identify patient-, trauma-, diagnosis- and treatment-related risk factors. Studies were included when infectious complications were assessed in light of one or more risk factors. A meta-analysis was performed. Risk Ratios (RR) or Risk Differences (RD) with 95\% confidence intervals were calculated.

Results 116 Manuscripts were included. Male gender (RR 1.42), DM (RR 1.72), smoking (RR1.29), a lower extremity fracture (RR 1.94), Gustilo-Anderson grade III open fracture (RR 3.01), contaminated fracture (RR 7.85) and polytrauma patients (RR 1.49) were identified as statistically significant risk factors for the development of infectious complications. Of the treatment related risk factors, only pulsatile lavage was associated with a higher infectious complication rate (RR 2.70).

Conclusion A number of risk factors for the development of infections after open fractures have been identified in the available literature. These factors should still be tested for independence in a multivariable model. Prospective, observational studies are needed to identify and quantify individual risk factors for infection after open fracture fixation.

Keywords: Open fractures; fracture fixation; infectious complications; risk factors 


\section{Introduction}

The development of infectious complications after open fractures is an often encountered problem, with a rate ranging from $<1 \%$ in grade I open fractures to $30 \%$ in grade III fractures[1-3]. Infections can be classified as acute, which includes superficial and deep soft tissue infections, and chronic infections, which are almost always bone infections, i.e., osteomyelitis[4]. Although the guidelines are quite clear, the use of these definitions in clinical practice is poor, and terms are often used interchangeably. It is important to keep in mind that even seemingly innocent superficial wound infections can progress into chronic osteomyelitis, of which the consequences can be severe. Patients often require more than one surgical debridement, are prescribed many different antibiotics, and still, the rate of amputation due to chronic osteomyelitis or severe soft tissue infection ranges from 4.2 to $10.6 \%[5-7]$. Preventing infection should therefore be one of the main goals in the primary treatment of a patient with a severe soft tissue injury[8].

Many patient- and treatment-related factors are believed to influence the development of infectious complications, but to date, a risk assessment model has not yet been established. Such a model could be a valuable aid for clinicians, helping them in delivering patient-tailored care. Risk assessment models have been proven helpful in clinical practice, of which the APACHE-II score for the risk of mortality of newly admitted ICU patients is one of the most wellknown[9]. But efforts have also been made to create risk models for the development of complications after trauma[10, 11].

There are a number of guidelines discussing protocols for debridement, fracture stabilization, and antibiotic prophylaxis[12, 13]. Some variations exist between hospitals, and local protocols may deviate from the described guidelines. In addition, the guidelines are based on a general population, and although some specifications are made (e.g., for Gustilo-Anderson grade), many other patient- or trauma-related risk factors are not taken into account. A large 
number of studies have assessed one or more risk factors in relation to infectious complications after open fractures, but many studies are retrospective, and populations are often small.

The aim of this study was to perform a systematic review and provide an overview of the risk factors for infectious complications in open fractures.

\section{Methods}

All aspects of the Cochrane Handbook for Interventional Systematic Reviews were followed and the study was written according to the Preferred Reporting Items for Systematic Reviews and Meta-Analyses (PRISMA) statement[14]. In addition, the Meta-analysis Of Observational Studies in Epidemiology (MOOSE) guidelines were used to assess case series[15]. Supplementary Figure 1 provides an overview of the definitions used in this review[4, 16].

Literature search strategy

A comprehensive search was performed with the help of a biomedical information specialist on March 302015 and updated on August 1 1s 2016, in Embase, Cochrane, Google Scholar, Medline (OvidSP), PubMed publisher and Web-of-Science. Only articles written in English were included, but no other limits were applied. Search strings for each database are provided in Appendix 1. All references were screened by the first reviewer (KK), and in case of doubt a second reviewer (MHJV) was consulted. In case of disagreement, a third reviewer would have been consulted, but consensus was reached for every case. Study selection was accomplished through two phases. During the first phase, titles and abstracts were reviewed for relevance, and full-text articles were obtained. Published meeting abstracts of which a full text was not yet published were excluded in order to prevent bias. During the second phase, full-text articles were reviewed. 
Studies were included when infectious complications were assessed in light of one or more potential risk factors. Each demographic, trauma-, injury- or treatment related factor that was described in the literature was included, there was no predefined list of factors to specifically search for. Only studies published within the last 30 years were included. Studies reporting on less than 50 patients were excluded. Studies only assessing treatment of non- or malunion, or long-term osteomyelitis occurring after 90 days as the only outcome measure were excluded, as were all animal studies.

An additional comparison was made between open and closed fractures, in order to assess whether an open fracture itself was a risk factor for infections. For this purpose, all articles found in the initial search that also included closed fractures were identified.

Full-text articles presenting preliminary results were included if they contained detailed data regarding infectious complications and one or more risk factors, and a full-text article describing the final data was not available. If data were unclear or pooled for closed and open fractures, the authors were requested to provide data for the open fracture subgroup alone. Authors were also contacted when two or more publications seemed to overlap. If no response was obtained after two reminders, articles with pooled or unclear fracture description were excluded. In cases of evident overlap, either the largest or most recent cohort was included. All references of included full text articles were manually screened in order to ensure that no relevant articles were missed.

\section{Data extraction and critical appraisal}

Data were collected on study design, population, affected bones, risk factors, and infectious complications. This was primarily done by one reviewer $(\mathrm{KK})$, and in case of doubt a second reviewer (MHJV) was consulted. The level of evidence of each paper was established using the Grades of Recommendation, Assessment, Development and Evaluation (GRADE) tool. The GRADE approach defines the quality of a body of evidence by consideration of risk of bias 
(methodological quality), directness of evidence, heterogeneity, precision of effect estimates, and risk of publication bias.

\section{Meta-analysis}

A meta-analysis was performed using SPSS version 21 and Review Manager version 5.3 (The Nordic Cochrane Center, Copenhagen, Denmark). Forest plots were created for the different risk factors encountered in the included studies. The first group of analyses was based on patient- and trauma-related factors. The last part consisted of analyses of treatment courserelated factors.

Patients with a certain potential risk factor were compared to those without that specific factor. Heterogeneity between studies was assessed by two methods. First, a Chi ${ }^{2}$ test was conducted, with a P-value $<0.1$ being considered statistically significant. In addition, $\mathrm{I}^{2}$ statistics were performed, using a cut-off point of $40 \%$. If no heterogeneity was observed a fixed effect model was used. If heterogeneity $\left(I^{2}>40 \%\right)$ remained present regardless of selectivity analysis, a random effect model was used. Results are presented in Risk Ratios (RR) or Risk Differences (RD) with a p-value or $95 \% \mathrm{Cl}$. P-values $<0.05$ were considered statistically significant. Forest plots were created to schematically demonstrate the effect of each risk factor. If heterogeneity was present, sensitivity analyses were performed for study design (i.e., only RCTs or only prospective studies), population (i.e., more than 100 or 250 patients) and year of publication (i.e., published after 2000). 


\section{Results}

A total of 3,490 unique studies were identified in the search. The flowchart in Figure 1 shows the selection process. Eleven authors were contacted, but unfortunately, either split data were not available or no response was obtained.

$\ll<$ Figure $1 \gg>$

After final selection 116 articles remained for inclusion in this review describing a total of 20,367 fractures (a reliable number of patients could not be calculated). The majority of included studies ( $n=79)$ were retrospective case series. Only eight randomized controlled trials (RCTs) were included, and the remaining 30 were prospective studies. A total of 17 pre-treatment potential risk factors, and eight treatment related potential risk factors were identified. The quality of evidence of the included studies was assessed per risk factor. Evidence on GustiloAnderson grade and antibiotic prophylaxis could be rated "moderate" if only RCTs were included, but evidence on all other risk factors was rated "low" or "very low" according to the GRADE criteria. The overview tables of quality of evidence per risk factor are attached as supplementary material (Appendix II). An overview of each risk factor found, and its association with the development of infectious complications in open fractures, is presented in Table 1.

$\ll<$ Table 1 $>>$

\section{Part I - patient and trauma-related factors}




\section{Age}

Thirteen articles mentioned age as a risk factor, most reported mean age $(\mathrm{N}=10,1,819$ fractures),[8, 17-25] others median age $(\mathrm{N}=3,1,477$ fractures)[26-28]. Using those that presented age in means with standard deviations (SD) did not demonstrate significant differences between infected and non-infected patients.

\section{Body Mass Index (BMI)}

BMI was only described in two articles[8, 19], both reporting mean values with SD. No significant difference was encountered between those with and without infectious complications.

\section{Gender}

Thirteen studies compared male and female patients (one RCT, three prospective and nine retrospective studies)[8, 17-21, 23-25, 29-32]. Male patients have a higher risk for developing infections: 16.1 versus 11.6\%, RR 1.42, p=0.004 (Figure 2).

$<<$ Figure $2>>>$

\section{Ethnicity}

One study compared Caucasian patients to non-Caucasian patients, and found no significant difference in infection rate, although 25.2 versus $10.5 \%$ may imply clinical relevance [23].

\section{American Society of Anesthesiologists (ASA)-score}

Two studies included the ASA-score in their risk analysis, however, one used a mean number of points with standard deviation[25] and the other a cut-off point of 2[24]. Neither found significant differences between the two groups. 


\section{Diabetes Mellitus}

Five studies described the rate of infectious complications in relation to diabetes (DM)[23-25, 27, 33]. Patients with DM developed significantly more post-traumatic infections: $25.3 \%$ versus 13.8\%, RR =1.72, p=0.01 (figure 3).

$<<$ FIGURE $3>>>$

\section{Human Immuno-deficiency Virus (HIV)}

Only two studies assessed HIV status[34, 35] Both were prospective cohort studies, HIV status was tested prospectively on admission in one study and retrospectively assessed in the other, allowing for possible bias. Although infection rate in HIV negative patients was lower than in HIV positive patients (21.0\% versus $13.1 \%)$, no significant difference was observed $(p=0.35)$.

\section{Hypertension and systemic vascular disease}

Two studies described either hypertension[23] or systemic vascular disease[24]. The first found no significant difference, but Molina et al. detected a higher incidence of infections in patients with systemic vascular disease (37.8 versus $18.1 \%, p=0.01)$. When bundled, a trend to significance was observed: 21.6 versus $18.6 \%, R R$ 1.60, $p=0.07$.

\section{Smoking, Alcohol, and Drugs}

Eleven studies (three prospective, eight retrospective) compared smokers with non-smokers with regard to infectious complications after open fractures[20, 23-25, 27, 33, 36-40]. Smokers had a significantly increased risk of infections: 17.7 versus $13.8 \%, R R 1.29, p=0.04$

$<<$ FIGURE $4>>>$ 
Alcohol was discussed in three articles[24, 25, 39] and drug use in two[25, 39]. . No significant differences in rate of infections were observed in these relatively small populations.

\section{Fracture localization}

A total of 27 studies described different fracture localizations (two RCTs, seven prospective and 18 retrospective studies, 6,425 fractures)[21, 22, 25, 28, 29, 32, 41-61]. Four only defined "upper" and "lower" extremity[21, 25, 42, 61], but the rest actually mentioned two or more specific bones. First, upper extremity fractures were compared to lower extremity fractures[21, $22,28,29,32,41-53]$. The latter were significantly more prone to developing infectious complications; $11.8 \%$ versus $5.4 \%$ ( $R R$ 1.94, $p=<0.0001$, Figure 5). However, there was significant heterogeneity between studies $\left(p=0.02, \mathrm{I}^{2}=44 \%\right)$. Sensitivity analysis was performed, but excluding either retrospective or older studies (i.e., publication date before 2000) did not result in less heterogeneity, nor did setting stricter limits for populations (i.e., more than 100 or more than 250 included patients).

$<<$ Figure $5>>>$

Second, infectious complications in specific bones were assessed. Calcaneal fractures demonstrated the highest univariate infection rate (25\%). However, calcaneal fractures were only specified in two articles[32, 44], adding up to four patients in total. Probably due to this small sample size, no significant difference was demonstrated $(p=0.09)$, even though the risk ratio for calcaneal fractures was 3.30 (95\% Cl 0.84-12.89).

The second highest infectious complication rate was seen in ankle fractures $(20.7 \%$, Table 1), which were described in nine studies[22, 32, 43, 48, 50, 51, 53, 60, 62]. There was no significant heterogeneity between these studies. Ankle fractures demonstrated a trend to statistical significance, with regard to infectious complications: RR 1.42, $p=0.07$. Femur $(p=0.73)$ 
and tibia $(p=0.11)$ fractures[22, 28, 29, 32, 41, 43-46, 48-51, 53-60, 62] did not demonstrate an increased risk of infections when individually compared to all other fractures, nor did any of the upper extremity fractures.

\section{Open versus closed fractures}

To assess whether open fractures alone were a risk factor for infections, they were compared to closed fractures. This resulted in a total of 51 articles[53, 56, 63-111], representing 2,980 open and 7,893 closed fractures. Infection rates were $4.2 \%$ for closed and $10.6 \%$ for open fractures. However, significant heterogeneity was detected when including all 51 articles. Excluding all retrospective case series eliminated this. Infections were still more frequently observed after open fractures; 11.4 versus 7.0\% (RR 2.60, $p<0.001$, Figure 6).

$<<$ Figure $6>>>$

\section{Gustilo-Anderson classification}

Most studies compared the three groups within the Gustilo-Anderson classification $(\mathrm{N}=84$, 16,331 fractures) $[8,17-19,21,24-26,29,30,33,35,36,39,41-44,46-51,54,56,59,67,72$, $76,79,94,100,111-161]$. Infection rates in grade III fractures was significantly higher than in grade I \& II fractures (15.9\% versus 5.1\%; RR 3.01, p<0.00001). Due to the multitude of studies heterogeneity was present $\left(1^{2}=47 \%\right)$. Excluding all retrospective studies still resulted in significant heterogeneity. When only randomized controlled trials were included ( $N=5,691$ fractures) $[50,131,132,142,160]$, heterogeneity was eliminated $\left(I^{2}=0 \%\right)$, and statistically significant differences were still present: 19.2 versus 7.2\%, RR 2.63, $\mathrm{p}<0.0001$ (Figure 7).

$<<$ Figure $7>>>$ 


\section{Contamination}

Three studies (one prospective, two retrospective, 880 fractures)[17, 29, 39] described contamination as a risk factor for infectious complications after open fractures. Although there was significant heterogeneity between studies, infections did occur more often in patients with contaminated wounds ( $R R 7.85, p=0.002$, figure 8$)$.

$<<<$ figure 8>>>

\section{Trauma mechanism}

Only three articles compared different trauma mechanisms, two prospective and one retrospective study (612 fractures)[22, 39, 53]. First, motor vehicle accidents (MVA) were compared to all other mechanisms of injury. No significant differences in infectious complication rates were observed. Pedestrians, gunshot wounds (GSW) and farmyard injuries were individually compared to all other mechanisms of injury due to their vulnerability or specific characteristics. The first two did not demonstrate any difference in risk ratios, however, farmyard injuries (although only described in one study) demonstrated significantly increased risk of infections: $100 \%$ versus $10.5 \%$ (Table $2, \mathrm{RR} 7.22, \mathrm{p}=0.0001$ ).

\section{Polytrauma versus monotrauma}

Four studies identified patients with polytrauma or monotrauma (one RCT, one prospective, two retrospective, 741 patients)[25, 32, 123, 129]. Infections developed more often in polytrauma patients (RR 1.49, $p=0.03$, Figure 9).

$<<<$ Figure $9>>>$ 


\section{Injury Severity Score (ISS)}

ISS was the most difficult factor to analyze. Although it was described in a total of ten articles, it was presented in a different manner in most of them. Four studies used cut-off points, $<13,<18$ and $<25[17,29,37,123]$. Four other studies used mean values for infected and non-infected fractures[18, 20, 22, 52], and the remaining two others used median values[27, 28]. Regardless of different presentations, no statistically significant association between ISS score and infection rates could be detected.

\section{Part II - treatment related risk factors}

\section{Antibiotic prophylaxis and timing thereof}

One prospective and two retrospective studies discussed the rate of infectious complications in relation to the timing of antibiotic prophylaxis[33, 46, 162]. No significant difference was encountered ( $R R$ 1.29, $p=0.52$ ) between early and late administration. In addition, there was some variability between the used cut-off points; two studies used a three hour limit to define early versus delayed, the third split their group in three; $<2$ hours, $2-4$ hours and $>4$ hours.

Two RCTs compared antibiotic prophylaxis with placebo[32, 163]. There was significant heterogeneity between the two studies $\left(I^{2}=49 \%\right)$, which can be explained by the fact that Braun[32] excluded finger fractures where Stevenson only included phalangeal fractures[163].

\section{Timing of debridement}

Eighteen studies (one RCT, three prospective, 17 retrospective) $[19,33,44,46-48,112,113$, $117,124,135,150,160,162,164-170]$ regarded infectious complications in relation to timing of debridement. As with antibiotic prophylaxis, cut-off points varied (limits set on five, six, eight or twelve hours), and selection bias may very well be present. No significant difference was observed between the early and the delayed group (RR 1.00, $p=0.99)$. 


\section{Pulsatile Lavage}

One article included pulsatile lavage as a potential risk factor for the development of infections, and found that it was indeed related to a higher infection rate as compared to high volume, low pressure washout of the fracture: 24 versus $9 \%, p=0.04[24]$.

\section{Fixation method}

Internal fixation was compared to external fixation in 16 studies (four RCTs, five prospective, eight retrospective) $[8,21,22,24,35,39,50,54,114,115,118,141,171-175]$. Heterogeneity was large $\left(p=<0.00001, I^{2}=79 \%\right)$; sensitivity analysis did not change this. Either way, no differences were encountered between the two techniques: $20.7 \%$ infections for internal fixation versus $23.6 \%$ for external fixation $(p=0.55)$. Including only RCTs to minimalize possible selection bias did not change this. Still, no apparent difference was observed between the internal or external fixation of open fractures $(p=0.16)$.

\section{Delayed wound closure}

Immediate versus delayed wound closure was addressed in four studies, two prospective and two retrospective[39, 123, 138, 151]. No differences were seen in the development of infectious complications (RR 0.95, p=0.91), but again selection bias may have been present. A fifth study compared wound closure $<72$ hours with closure $>72$ hours after trauma, and found no difference in infection rate. However; when patients who underwent single-stage orthoplastic fixation and coverage were compared to those who had multiple reconstructive surgeries, a difference was found in favor of the single-stage patients: $4.2 \%$ versus $34.6 \%$ developed an infectious complication $(p<0.001)[176]$. 


\section{Blood transfusion}

Only two studies described blood transfusion as a risk factor for infectious complications[22, 41]. Both were prospective, and no heterogeneity was encountered. With $13.7 \%$ infections for patients who did receive a blood transfusion versus $6.2 \%$ for those who did not, blood transfusion seems to be a risk factor for the development of infectious complications (RR 2.08, $\mathrm{p}=0.0004$, Figure 10).

$\ll<$ Figure $10>>>$

\section{Splenectomy}

Only one study compared patients who underwent splenectomy with patients who did not[177]. Infectious complication rates were evidently increased for the first group; 25.0 versus $4.7 \%$. With a RR of 5.38 splenectomy seems to be a risk factor for the development of infections, but due to the small number of patients this did not reach statistical significance $(p=0.07)$. 


\section{Discussion}

This systematic review and meta-analysis are, to the best of our knowledge, the first to bundle all available evidence regarding risk factors for infectious complications after surgically treated open fractures. An extensive literature search has been performed, and a large number of articles were found, comprising more than 20,000 individual fractures. A number of factors were identified that seem to increase the infectious complication rate: male gender, DM, smoking, polytrauma status, lower extremity fractures, Gustilo-Anderson grade III fractures and contaminated wounds.

Unfortunately, the level of evidence was low, and caution is warranted with the interpretation of these results. Possible confounding cannot be detected by means of a meta-analysis, and multivariable analysis of a large study population should be performed in order to assess this issue. Some other possible risk factors, which have been demonstrated to influence the development of infectious complications in elective general surgical and orthopedic procedures (e.g. BMI[178], alcohol/drug abuse[179-181]) were not identified as risk factors in this metaanalysis. This may again be explained by the low levels of evidence of the included studies, the possibility of confounding, and the fact that some factors were only sporadically described in the available literature, and population numbers were too low to detect statistical significance. A large number of other possible risk factors were not addressed at all in the identified studies, but may still be important in the development of infections after open fracture treatment (e.g., malnutrition, renal disease,[182, 183], liver disease[184, 185]).

This meta-analysis has a number of limitations. Many studies were retrospective, making data less reliable. Smaller studies (i.e., less than 50 patients) were excluded to prevent false negative results. Because of the prevalence of many risk factors in the general population, chances are that these risk factors would not be present at all within a small study group. 
Moreover, including these small studies would not increase the grade of evidence of this metaanalysis.

For some risk factors selection bias was highly suspected. It is, for instance, conceivable that external fixation may have been the treatment of choice in Gustilo-Anderson grade III fractures where internal fixation would have been chosen for the majority of grade I fractures. Gosselin et al. showed that antibiotic prophylaxis prevents infection in patients with open fractures[186]. The focus in this review was on timing of antibiotic prophylaxis, but it is again quite understandable that patients with Gustilo-Anderson grade III fractures were more likely to undergo debridement and receive antibiotic prophylaxis sooner than those with grade I fractures. Unfortunately, most articles only described either the Gustilo-Anderson grade in relation to infections, or the treatment modality. It is thus hard to deduct which factor presents the largest risk of infectious complications.

Heterogeneity between studies was a problem for a number of analyses. A number of studies only included Gustilo-Anderson grade III fractures, which in itself is a risk factor for infectious complications. Whether these studies can be compared with studies pooling all grades is debatable. Some studies were conducted in a pediatric population, which could account for a lower complication rate. The extremities included in the different studies varied, which may also result in heterogeneity. As has been previously demonstrated, lower extremity fractures are at greater risk for the development of infectious complications[41, 43, 49, 53], and it may not be valid to compare studies only including tibial fractures with those that pool upper and lower extremity fractures and publish one infectious complication rate for the entire study population. Some authors separately reported superficial and deep infections, others only included those patients who developed deep infections and yet others did not further specify their outcome. Overall, the definition for infection, as well as for the included risk factors varied between the studies. 
Ideally, reliably quantified risk factors should be assembled into a mathematical formula that can predict the infection risk for an individual patient and guide therapeutic strategies. However, the current data are insufficient to build such a risk-assessment model. Although some risk factors were identified, these should still be tested for independence in a multivariable model. On the other hand, factors that have been investigated but did not appear to be risk factors for infection in this meta-analysis might have been erroneously excluded, due to, for instance, small sample sizes or confounding. The only way to improve the reliability and quantitative influence of the possible risk factors for infection, is a large, prospective database, incorporating all imaginable risk factors. Only after such a study, a high-quality risk-assessment model can be built. Once the data for such a model is available, the methods previously described by de Jongh et al.[10] could serve as a guideline to develop the infection prediction model.

\section{Acknowledgements}

The authors thank Mr. Wichor M. Bramer, biomedical information specialist (Erasmus MC, University Medical Center Rotterdam, Rotterdam, The Netherlands), for his help in conducting the systematic literature search.

\section{Compliance with Ethical Standards}

\section{Conflict of Interest}

The authors have no conflicts of interest to disclose.

\section{Funding}

There is no funding source

\section{Ethical Approval}

This article does not contain any studies with human participants or animals performed by any of the authors. 


\section{Informed Consent}

Informed consent was not applicable in this study. 


\section{References}

1. Papakostidis C, Kanakaris NK, Pretel J, Faour O, Morell DJ, Giannoudis PV (2011) Prevalence of complications of open tibial shaft fractures stratified as per the Gustilo-Anderson classification. Injury 42:1408-1415. DOI 10.1016/j.injury.2011.10.015

2. Gustilo RB, Mendoza RM, Williams DN (1984) Problems in the management of type III (severe) open fractures: A new classification of type III open fractures. J Trauma 24:742-746

3. Ktistakis I, Giannoudi M, Giannoudis PV (2014) Infection rates after open tibial fractures: are they decreasing? Injury 45:1025-1027. DOI S0020-1383(14)00162-4 [pii]

10.1016/j.injury.2014.03.022

4. CDC (1999) Guideline for Prevention of Surgical Site Infection. In.

5. Kanakaris N, Gudipati S, Tosounidis T, Harwood P, Britten S, Giannoudis PV (2014) The treatment of intramedullary osteomyelitis of the femur and tibia using the Reamer-Irrigator-Aspirator system and antibiotic cement rods. Bone Joint J 96 B:783-788. DOI 10.1302/0301-620x.96b6.32244

6. Huh J, Stinner DJ, Burns TC, Hsu JR (2011) Infectious complications and soft tissue injury contribute to late amputation after severe lower extremity trauma. J Trauma Inj Infect Crit Care 71:S47-S51. DOI 10.1097/TA.0b013e318221181d

7. Bose $D$, Kugan R, Stubbs D, McNally M (2015) Management of infected nonunion of the long bones by a multidisciplinary team. Bone Joint J 97-B:814-817. DOI 97-B/6/814 [pii]

10.1302/0301-620X.97B6.33276

8. Matos MA, Lima LG, de Oliveira LAA (2015) Predisposing factors for early infection in patients with open fractures and proposal for a risk score. J Orthop Traumatol 16:195-201. DOI 10.1007/s10195-0150345-z

9. Knaus WA, Draper EA, Wagner DP, Zimmerman JE (1985) APACHE II: a severity of disease classification system. Crit Care Med 13:818-829

10. de Jongh MA, Bosma E, Verhofstad MH, Leenen LP (2011) Prediction models for complications in trauma patients. Br J Surg 98:790-796. DOI 10.1002/bjs.7436

11. Santolini E, West R, Giannoudis PV (2015) Risk factors for long bone fracture non-union: a stratification approach based on the level of the existing scientific evidence. Injury 46 Suppl 8:S8-S19. DOI S0020-1383(15)30049-8 [pii]

10.1016/S0020-1383(15)30049-8

12. Hoff WS, Bonadies JA, Cachecho R, Dorlac WC (2011) East practice management guidelines work group: Update to practice management guidelines for prophylactic antibiotic use in open fractures. J Trauma Inj Infect Crit Care 70:751-754. DOI 10.1097/TA.0b013e31820930e5

13. BAPRAS BOA. In.

14. Moher D, Liberati A, Tetzlaff J, Altman DG, Group P (2009) Preferred reporting items for systematic reviews and meta-analyses: the PRISMA statement. Ann Intern Med 151:264-269, W264. DOI 0000605200908180-00135 [pii]

15. Stroup DF, Berlin JA, Morton SC, Olkin I, Williamson GD, Rennie D, Moher D, Becker BJ, Sipe TA, Thacker SB (2000) Meta-analysis of observational studies in epidemiology: a proposal for reporting. Meta-analysis Of Observational Studies in Epidemiology (MOOSE) group. JAMA 283:2008-2012. DOI jst00003 [pii]

16. Gustilo RB, Anderson JT (1976) Prevention of infection in the treatment of one thousand and twenty five open fractures of long bones: retrospective and prospective analyses. J Bone Joint Surg Am 58:453458 
17. Hull PD, Johnson SC, Stephen DJG, Kreder HJ, Jenkinson RJ (2014) Delayed debridement of severe open fractures is associated with a higher rate of deep infection. Bone Jt J 96 B:379-384. DOI 10.1302/0301-620x.96b3

18. Yusof NM, Khalid KA, Zulkifly AH, Zakaria Z, Amin MAM, Awang MS, Ahmad AC, Akter SFU (2013) Factors associated with the outcome of open tibial fractures. Malays J Med Sci 20:47-53

19. Chen AF, Schreiber VM, Washington W, Rao N, Evans AR (2013) What is the rate of methicillinresistant staphylococcus aureus and gram-negative infections in open fractures? Clin Orthop Relat Res 471:3135-3140. DOI 10.1007/s11999-013-2855-4

20. Enninghorst N, McDougall D, Hunt JJ, Balogh ZJ (2011) Open tibia fractures: Timely debridement leaves injury severity as the only determinant of poor outcome. J Trauma Inj Infect Crit Care 70:352-357. DOI 10.1097/TA.0b013e31820b4285

21. Vainionpaa S, Vasenius J, Rokkanen P (1990) Benzylpenicillin ineffective for open fractures. Prospective study of 60 cases. Acta Orthop Scand 61:158-160

22. Dellinger EP, Miller SD, Wertz MJ, Grypma M, Droppert B, Anderson PA (1988) Risk of infection after open fracture of the arm or leg. Arch Surg 123:1320-1327

23. Molina CS, Stinner DJ, Fras AR, Evans JM (2015) Risk factors of deep infection in operatively treated pilon fractures (AO/OTA: 43). J Orthop 12:S7-S13

24. Ovaska MT, Madanat R, Mäkinen TJ (2016) Predictors of Postoperative Wound Necrosis Following Primary Wound Closure of Open Ankle Fractures. Foot Ankle Int 37:401-406

25. Lawing CR, Li FC, Dahners LE (2015) Local injection of aminoglycosides for prophylaxis against infection in open fractures. J Bone Jt Surg Am Vol 97:1844-1851

26. Dunkel N, Pittet D, Tovmirzaeva L, Suva D, Bernard L, Lew D, Hoffmeyer P, Uckay I (2013) Short duration of antibiotic prophylaxis in open fractures does not enhance risk of subsequent infection. Bone Jt J 95 B:831-837. DOI 10.1302/0301-620x.95b6.30114

27. Lack WD, Karunakar MA, Angerame MR, Seymour RB, Sims S, Kellam JF, Bosse MJ (2015) Type III open tibia fractures: Immediate antibiotic prophylaxis minimizes infection. J Orthop Trauma 29:1-6. DOI 10.1097/bot.0000000000000262

28. Brown KV, Murray CK, Clasper JC (2010) Infectious Complications of Combat-Related Mangled Extremity Injuries in the British Military. Journal of Trauma-Injury Infection and Critical Care 69:S109S115

29. Yokoyama K, Itoman M, Nakamura K, Uchino M, Nitta H, Kojima Y (2009) New scoring system predicting the occurrence of deep infection in open upper and lower extremity fractures: Efficacy in retrospective re-scoring. Arch Orthop Trauma Surg 129:469-474. DOI 10.1007/s00402-008-0675-x

30. Hohmann E, Tetsworth K, Radziejowski MJ, Wiesniewski TF (2007) Comparison of delayed and primary wound closure in the treatment of open tibial fractures. Arch Orthop Trauma Surg 127:131-136. DOI 10.1007/s00402-006-0222-6

31. Ikem IC, Oginni LM, Ogunlusi JD (2006) Determinants of management outcome in open tibia fractures in Ile-Ife. Niger J Surg Res 8:81-85

32. Braun R, Enzler MA, Rittmann WW (1987) A double-blind clinical trial of prophylactic cloxacillin in open fractures. J Orthop Trauma 1:12-17

33. Zumsteg JW, Molina CS, Lee DH, Pappas ND (2014) Factors influencing infection rates after open fractures of the radius and/or ulna. J Hand Surg (USA) 39:956-961. DOI 10.1016/j.jhsa.2014.02.008

34. Aird J, Noor S, Lavy C, Rollinson P (2011) The effect of HIV on early wound healing in open fractures treated with internal and external fixation. J Bone Jt Surg Ser B 93 B:678-683. DOI 10.1302/0301620x.93b5.26081

35. Howard NE, Phaff M, Aird J, Wicks L, Rollinson P (2013) Does human immunodeficiency virus status affect early wound healing in open surgically stabilised tibial fractures? A prospective study. Bone Jt J 95 B:1703-1707. DOI 10.1302/0301-620x.95b12.32083 
36. Reuss BL, Cole JD (2007) Effect of delayed treatment on open tibial shaft fractures. Am J Orthop $36: 215-220$

37. Castillo RC, Bosse MJ, MacKenzie EJ, Patterson BM, Burgess AR, Jones AL, Kellam JF, McAndrew MP, McCarthy ML, Rohde CA, Sanders R, Swiontkowski MF, Webb LX, Agel J, Avery J, Bailey D, Bryan W, Bullard D, Carpenter C, Chaparro E, Corbin K, Darnell D, Dickason S, DiPasquale T, Harkin B, Harrington $M$, Herscovici D, Holdren A, Howard L, Hutchings S, Johnson M, Jurewicz M, Lampke D, Lee K, Mars $M$, Mendoza-Welch M, Meredith JW, Morris N, Murdock K, Pollak A, Radey P, Shelton S, Simpson S, Sims S, Smith D, Starr A, Weigman C, Wilber J, Williams S, Wolinsky P, Woodman M, Zimmerman M (2005) Impact of smoking on fracture healing and risk of complications in limb-threatening open tibia fractures. J Orthop Trauma 19:151-157. DOI 10.1097/00005131-200503000-00001

38. Adams Cl, Keating JF, Court-Brown CM (2001) Cigarette smoking and open tibial fractures. Injury 32:61-65

39. Merritt K (1988) Factors increasing the risk of infection in patients with open fractures. J Trauma 28:823-827

40. Penn-Barwell JG, Bennett PM, Mortiboy DE, Fries CA, Groom AFG, Sargeant ID (2016) Factors influencing infection in 10 years of battlefield open tibia fractures. Strategies Trauma Limb Reconst 11:13-18

41. Weber D, Dulai SK, Bergman J, Buckley R, Beaupre LA (2014) Time to initial operative treatment following open fracture does not impact development of deep infection: A prospective cohort study of 736 subjects. J Orthop Trauma 28:613-619

42. Malhotra AK, Goldberg S, Graham J, Malhotra NR, Willis MC, Mounasamy V, Guilford K, Duane TM, Aboutanos MB, Mayglothling J, Ivatury RR (2014) Open extremity fractures: Impact of delay in operative debridement and irrigation. J Trauma Acute Care Surg 76:1201-1207. DOI 10.1097/ta.0000000000000205

43. Moola FO, Carli A, Berry GK, Reindl R, Jacks D, Harvey EJ (2014) Attempting primary closure for all open fractures: the effectiveness of an institutional protocol. Can J Surg 57:E82-88

44. Arti HR (2012) Comparison of early versus delayed debridement in open fractures. Pak J Med Sci 28:856-859

45. Rajasekaran S, Dheenadhayalan J, Babu JN, Sundararajan SR, Venkatramani H, Sabapathy SR (2009) Immediate primary skin closure in type-III A and B open fractures: Results after a minimum of five years. J Bone Jt Surg Ser B 91:217-224. DOI 10.1302/0301-620x.91b2.21228

46. Al-Arabi YB, Nader M, Hamidian-Jahromi AR, Woods DA (2007) The effect of the timing of antibiotics and surgical treatment on infection rates in open long-bone fractures: A 9-year prospective study from a district general hospital. Injury 38:900-905. DOI 10.1016/j.injury.2007.02.043

47. Skaggs DL, Friend L, Alman B, Chambers HG, Schmitz M, Leake B, Kay RM, Flynn JM (2005) The effect of surgical delay on acute infection following 554 open fractures in children. J Bone Jt Surg Ser A 87:8-12. DOI 10.2106/jbjs.c.01561

48. Spencer J, Smith A, Woods D (2004) The effect of time delay on infection in open long-bone fractures: A 5-year prospective audit from a district general hospital. Ann R Coll Surg Engl 86:108-112. DOI 10.1308/003588404322827491

49. Harley BJ, Beaupre LA, Jones CA, Dulai SK, Weber DW (2002) The effect of time to definitive treatment on the rate of nonunion and infection in open fractures. J Orthop Trauma 16:484-490. DOI 10.1097/00005131-200208000-00006

50. Patzakis MJ, Bains RS, Lee J, Shepherd L, Singer G, Ressler R, Harvey F, Holtom P (2000) Prospective, randomized, double-blind study comparing single-agent antibiotic therapy, ciprofloxacin, to combination antibiotic therapy in open fracture wounds. J Orthop Trauma 14:529-533

51. Yokoyama K, Shindo M, Itoman M, Yamamoto M, Sasamoto N (1994) Immediate internal fixation for open fractures of the long bones of the upper and lower extremities. J Trauma 37:230-236 
52. Ostermann PAW, Henry SL, Seligson D (1992) Injury Severity Score compared to other risk factors for infection after compound fracture. Theor Surg 7:177-179

53. Roth Al, Fry DE, Polk Jr HC (1986) Infectious morbidity in extremity fractures. J Trauma 26:757-761

54. Dickens JF, Kilcoyne KG, Kluk MW, Gordon WT, Shawen SB, Potter BK (2013) Risk factors for infection and amputation following open, combat-related calcaneal fractures. J Bone Jt Surg Ser A 95:e241-e248. DOI 10.2106/jbjs.I.00003

55. Ikem IC, Oginni LM, Bamgboye EA (2001) Open fractures of the lower limb in Nigeria. Int Orthop 25:386-388. DOI 10.1007/s002640100277

56. Jenny JY, Jenny G, Kempf I (1994) Infection after reamed intramedullary nailing of lower limb fractures: A review of 1,464 cases over 15 years. Acta Orthop Scand 65:94-96

57. Kaltenecker G, Wruhs O, Quaicoe S (1990) Lower infection rate after interlocking nailing in open fractures of femur and tibia. J Trauma 30:474-479

58. Mody RM, Zapor M, Hartzell JD, Robben PM, Waterman P, Wood-Morris R, Trotta R, Andersen RC, Wortmann G (2009) Infectious complications of damage control orthopedics in war trauma. J Trauma Inj Infect Crit Care 67:758-761. DOI 10.1097/TA.0b013e3181af6aa6

59. Rodriguez L, Jung HS, Goulet JA, Cicalo A, Machado-Aranda DA, Napolitano LM (2014) Evidencebased protocol for prophylactic antibiotics in open fractures: Improved antibiotic stewardship with no increase in infection rates. J Trauma Acute Care Surg 77:400-408. DOI 10.1097/ta.0000000000000398

60. Haller JM, Holt D, Rothberg DL, Kubiak EN, Higgins TF (2016) Does Early versus Delayed Spanning External Fixation Impact Complication Rates for High-energy Tibial Plateau and Plafond Fractures? Clin Orthop Relat Res 474:1436-1444

61. Johnson JP, Karam M, Schisel J, Agel J (2016) An evaluation of the OTA-OFC system in clinical practice: A multi-center study with 90 day outcomes. J Orthop Trauma

62. Skaggs DL, Kautz SM, Kay RM, Tolo VT (2000) Effect of delay of surgical treatment on rate of infection in open fractures in children. J Pediatr Orthop 20:19-22. DOI 10.1097/00004694-200001000-00005

63. Abdelgawad AA, Sieg RN, Laughlin MD, Shunia J, Kanlic EM (2013) Submuscular bridge plating for complex pediatric femur fractures is reliable. Clin Orthop Relat Res 471:2797-2807. DOI 10.1007/s11999-013-2931-9

64. Bannasch H, Heermann AK, Iblher N, Momeni A, Schulte-Monting J, Stark GB (2010) Ten years stable internal fixation of metacarpal and phalangeal hand fractures - Risk factor and outcome analysis show no increase of complications in the treatment of open compared with closed fractures. J Trauma Inj Infect Crit Care 68:624-628. DOI 10.1097/TA.0b013e3181bb8ea0

65. Colman M, Wright A, Gruen G, Siska P, Pape HC, Tarkin I (2013) Prolonged operative time increases infection rate in tibial plateau fractures. Injury 44:249-252. DOI 10.1016/j.injury.2012.10.032

66. Costigan W, Thordarson DB, Debnath UK (2007) Operative management of ankle fractures in patients with diabetes mellitus. Foot Ankle Int 28:32-37. DOI 10.3113/fai.2007.0006

67. Court-Brown CM, Keating JF, McQueen MM (1992) Infection after intramedullary nailing of the tibia: Incidence and protocol for management. J Bone Joint Surg $\mathrm{Br}$ 74:770-774

68. Dewall M, Henderson CE, McKinley TO, Phelps T, Dolan L, Marsh JL (2010) Percutaneous reduction and fixation of displaced intra-articular calcaneus fractures. J Orthop Trauma 24:466-472. DOI 10.1097/BOT.0b013e3181defd74

69. Finkemeier CG, Schmidt AH, Kyle RF, Templeman DC, Varecka TF (2000) A prospective, randomized study of intramedullary nails inserted with and without reaming for the treatment of open and closed fractures of the tibial shaft. J Orthop Trauma 14:187-193

70. Fusetti C, Meyer H, Borisch N, Stern R, Della Santa D, Papaloizos M (2002) Complications of plate fixation in metacarpal fractures. J Trauma Inj Infect Crit Care 52:535-539

71. Gadegone W, Salphale YS, Lokhande V (2012) Screw elastic intramedullary nail for the management of adult forearm fractures. Indian j orthop 46:65-70 
72. Gaebler C, Berger U, Schandelmaier P, Greitbauer M, Schauwecker HH, Applegate B, Zych G, Vecsei V (2001) Rates and odds ratios for complications in closed and open tibial fractures treated with unreamed, small diameter tibial nails: A multicenter analysis of 467 cases. J Orthop Trauma 15:415-423. DOI 10.1097/00005131-200108000-00006

73. Hak DJ, Lee M, Gotham DR (2010) Influence of prior fasciotomy on infection after open reduction and internal fixation of tibial plateau fractures. J Trauma 69:886-888

74. Hoffmann MF, Jones CB, Sietsema DL, Tornetta 3rd P, Koenig SJ (2013) Clinical outcomes of locked plating of distal femoral fractures in a retrospective cohort. J Orthop Surg Res 8:43

75. Hoiness P, Stromsoe K (1999) Early complications of surgically managed ankle fractures related to the AO classification. A review of 118 ankle fractures treated with open reduction and internal fixation. Arch Orthop Trauma Surg 119:276-279. DOI 10.1007/s004020050409

76. Howard, Dm Z (1992) The Use of the Lottes Nail in the Treatment of Closed and Open Tibia1 Shaft Fractures. Clin Orthop Relat Res 279:246-253

77. J. J. Hutson J, Zych GA (1998) Infections in periarticular fractures of the lower extremity treated with tensioned wire hybrid fixators. Journal of Orthopaedic Trauma 12:214-218

78. Kadar A, Sherman H, Glazer Y, Katz E, Steinberg EL (2014) Predictors for nonunion, reoperation and infection after surgical fixation of patellar fracture. J Ortop Sci 20:168-173. DOI 10.1007/s00776-0140658-4

79. Karadimas EJ, Papadimitriou G, Theodoratos G, Papanikolaou A, Maris J (2009) The effectiveness of the antegrade reamed technique: the experience and complications from 415 traumatic femoral shaft fractures. Strategies Trauma Limb Reconstr 4:113-121

80. Karunakar MA, Staples KS (2010) Does stress-induced hyperglycemia increase the risk of perioperative infectious complications in orthopaedic trauma patients? J Orthop Trauma 24:752-756. DOI 10.1097/BOT.0b013e3181d7aba5

81. Klemm KW, Borner M (1986) Interlocking nailing of complex fractures of the femur and tibia. Clin Orthop:89-100

82. Kline AJ, Gruen GS, Pape HC, Tarkin IS, Irrgang JJ, Wukich DK (2009) Early complications following the operative treatment of pilon fractures with and without diabetes. Foot Ankle Int 30:1042-1047. DOI 10.3113/fai.2009.1042

83. Kregor PJ, Stannard JA, Zlowodzki M, Cole PA (2004) Treatment of distal femur fractures using the Less Invasive Stabilization System: Surgical experience and early clinical results in 103 fractures. J Orthop Trauma 18:509-520. DOI 10.1097/00005131-200409000-00006

84. Kurzen P, Fusetti C, Bonaccio M, Nagy L (2006) Complications after plate fixation of phalangeal fractures. J Trauma Inj Infect Crit Care 60:841-843. DOI 10.1097/01.ta.0000214887.31745.c4

85. Laible C, Earl-Royal E, Davidovitch R, Walsh M, Egol KA (2012) Infection after spanning external fixation for high-energy tibial plateau fractures: Is pin site-plate overlap a problem? J Orthop Trauma 26:92-97. DOI 10.1097/BOT.0b013e31821cfb7a

86. Larsen SE, Nielsen KS, Larsen MS, Kristensen SS (2000) Treatment of femoral shaft fractures with Grosse-Kempf intramedullary nail. J Ortop Sci 5:328-332. DOI 10.1007/s007760070038

87. Lawrence TM, Ahmadi S, Morrey BF, Sanchez-Sotelo J (2014) Wound complications after distal humerus fracture fixation: incidence, risk factors, and outcome. J Shoulder Elbow Surg 23:258-264

88. Lee YS, Chen SH, Lin JC, Chen YO, Huang CR, Cheng CY (2009) Surgical treatment of distal tibia fractures: A comparison of medial and lateral plating. Orthopedics 32:163

89. Lee YS, Lo TY, Huang HL (2008) Intramedullary fixation of tibial shaft fractures: A comparison of the unlocked and interlocked nail. Int Orthop 32:69-74. DOI 10.1007/s00264-006-0271-z

90. Leung F, Chow SP (2003) A Prospective, Randomized Trial Comparing the Limited Contact Dynamic Compression Plate with the Point Contact Fixator for Forearm Fractures. J Bone Jt Surg Ser A 85:23432348 
91. Linn MS, Gardner MJ, McAndrew CM, Gallagher B, Ricci WM (2014) Is primary total elbow arthroplasty safe for the treatment of open intra-articular distal humerus fractures? Injury 45:17471751. DOI 10.1016/j.injury.2014.07.017

92. Liu F, Tao R, Cao Y, Wang Y, Zhou Z, Wang H, Gu Y (2009) The role of LISS (less invasive stabilisation system) in the treatment of peri-knee fractures. Injury 40:1187-1194. DOI 10.1016/j.injury.2009.03.012 93. Malik MHA, Harwood P, Diggle P, Khan SA (2004) Factors affecting rates of infection and nonunion in intramedullary nailing. J Bone Jt Surg Ser B 86:556-560

94. Morris BJ, Unger RZ, Archer KR, Mathis SL, Perdue AM, Obremskey WT (2013) Risk factors of infection after ORIF of bicondylar tibial plateau fractures. J Orthop Trauma 27:e196-e200. DOI 10.1097/BOT.0b013e318284704e

95. Murphy CP, D'Ambrosia RD, Dabezies EJ, Acker JH, Shoji H, Chuinard RG (1988) Complex femur fractures: treatment with the wagner external fixation device or the Grosse-Kempf interlocking nail. J Trauma 28:1553-1561

96. Paiement GD, Hymes RA, LaDouceur MS, Gosselin RA, Green HD, DeLong Jr WG, Rosner MJ, Bender JS, Carrico CJ (1994) Postoperative infections in asymptomatic HIV-seropositive orthopedic trauma patients. J Trauma 37:545-551

97. Ramasamy PR (2009) The significance of segmental fibular fractures in the management of associated tibial fractures. Injury 40:327-332. DOI 10.1016/j.injury.2008.07.014

98. Ricci WM, Streubel PN, Morshed S, Collinge CA, Nork SE, Gardner MJ (2014) Risk factors for failure of locked plate fixation of distal femur fractures: An analysis of 335 cases. J Orthop Trauma 28:83-89. DOI 10.1097/BOT.0b013e31829e6dd0

99. Richards JE, Hutchinson J, Mukherjee K, Jahangir AA, Mir HR, Evans JM, Perdue AM, Obremskey WT, Sethi MK, May AK (2014) Stress hyperglycemia and surgical site infection in stable nondiabetic adults with orthopedic injuries. J Trauma Acute Care Surg 76:1070-1075. DOI 10.1097/ta.0000000000000177 100. Richards JE, Kauffmann RM, Obremskey WT, May AK (2013) Stress-induced hyperglycemia as a risk factor for surgical-site infection in nondiabetic orthopedic trauma patients admitted to the intensive care unit. J Orthop Trauma 27:16-21. DOI 10.1097/BOT.0b013e31825d60e5

101. Riemer BL, DiChristina DG, Cooper A, Sagiv S, Butterfield SL, Burke 3rd CJ, Lucke JF, Schlosser JD (1995) Nonreamed nailing of tibial diaphyseal fractures in blunt polytrauma patients. J Orthop Trauma 9:66-75

102. Ruffolo MR, Gettys FK, Montijo HE, Seymour RB, Karunakar MA (2015) Complications of highenergy bicondylar tibial plateau fractures treated with dual plating through 2 incisions. J Orthop Trauma 29:85-90. DOI 10.1097/bot.0000000000000203

103. Schepers T, Den Hartog D, Vogels LMM, Van Lieshout EMM (2013) Extended Lateral Approach for Intra-articular Calcaneal Fractures: An Inverse Relationship between Surgeon Experience and Wound Complications. J Foot Ankle Surg 52:167-171. DOI 10.1053/j.jfas.2012.11.009

104. Sie E, Kacou A, Traore A, Sery B, Lambin Y (2012) Primary unreamed and unlocked intramedullary nailing of femoral shaft fractures. Malays Orthop J 6:13-17

105. Smith ST, Cramer KE, Karges DE, Watson JT, Moed BR (1997) Early complications in the operative treatment of patella fractures. J Orthop Trauma 11:183-187

106. Sodergard J, Sandelin J, Bostman O (1992) Postoperative complications of distal humeral fractures. 27/96 adults followed up for 6 (2-10) years. Acta Orthop Scand 63:85-89

107. Stannard JP, Volgas DA, McGwin G, Stewart RL, Obremskey W, Moore T, Anglen JO (2012) Incisional Negative Pressure Wound Therapy After High-Risk Lower Extremity Fractures. Journal of Orthopaedic Trauma 26:37-42

108. van der Linden SC, van Kampen A, Jaarsma RL (2012) K-wire position in tension-band wiring technique affects stability of wires and long-term outcome in surgical treatment of olecranon fractures. J Shoulder Elbow Surg 21:405-411. DOI 10.1016/j.jse.2011.07.022 
109. White TO, Guy P, Cooke CJ, Kennedy SA, Droll KP, Blachut PA, O'Brien PJ (2010) The results of early primary open reduction and internal fixation for treatment of OTA 43.C-type tibial pilon fractures: A cohort study. J Orthop Trauma 24:757-763. DOI 10.1097/BOT.0b013e3181d04bc0

110. Wilson FC, Dirschl DR, Bynum DK (1997) Fractures of the radius and ulna in adults: an analysis of factors affecting outcome. lowa Orthop J 17:14-19

111. Wolinsky PR, McCarty E, Shyr Y, Johnson K (1999) Reamed intramedullary nailing of the femur: 551 cases. J Trauma Inj Infect Crit Care 46:392-399

112. Charalambous CP, Siddique I, Zenios M, Roberts S, Samarji R, Paul A, Hirst P (2005) Early versus delayed surgical treatment of open tibial fractures: Effect on the rates of infection and need of secondary surgical procedures to promote bone union. Injury 36:656-661. DOI 10.1016/j.injury.2004.10.007

113. Kamat AS (2011) Infection rates in open fractures of the tibia: is the 6-hour rule fact or fiction? Adv orthop 2011:943495

114. Russell GG, Henderson R, Arnett G (1990) Primary or delayed closure for open tibial fractures. J Bone Joint Surg Br 72:125-128

115. Khatod M, Botte MJ, Hoyt DB, Meyer RS, Smith JM, Akeson WH (2003) Outcomes in Open Tibia Fractures: Relationship between Delay in Treatment and Infection. J Trauma Inj Infect Crit Care 55:949954. DOI 10.1097/01.ta.0000092685.80435.63

116. Stannard JP, Finkemeier CG, Lee J, Kregor PJ (2008) Utilization of the less-invasive stabilization system internal fixator for open fractures of the proximal tibia: a multi-center evaluation. Indian j orthop 42:426-430

117. Tripuraneni K, Ganga S, Quinn R, Gehlert R (2008) The effect of time delay to surgical debridement of open tibia shaft fractures on infection rate. Orthopedics 31:1195

118. Leong CM, Leong AP, Low BY (1988) Management of open tibia fractures. Singapore Med J 29:42-44 119. Clifford RP, Beauchamp CG, Kellam JF, Webb JK, Tile M (1988) Plate fixation of open fractures of the tibia. J Bone Joint Surg $\mathrm{Br}$ 70:644-648

120. Ali MH, Hoekzerna NA, Bakleh M, Shin AY, Osmon DR (2008) The microbiology and risk of infection following open, agricultural upper extremity injuries. Journal of Hand Surgery-American Volume 33A:8793

121. Wang HC, Kan SL, Shu HS, Pang GG, Zhang YF (2010) Immediate internal fixation of open ankle fractures. Foot Ankle Int 31:959-964. DOI 10.3113/fai.2010.0959

122. Wiersema B, Brokaw D, Weber T, Psaradellis T, Panero C, Weber C, Musapatika D (2011) Complications associated with open calcaneus fractures. Foot Ankle Int 32:1052-1057. DOI 10.3113/fai.2011.1052

123. Green A, Trafton PG (1991) Early complications in the management of open femur fractures: a retrospective study. J Orthop Trauma 5:51-56

124. O'Brien PJ, Meek RN, Powell JN, Blachut PA (1991) Primary intramedullary nailing of open femoral shaft fractures. J TRAUMA 31:113-116

125. Luhmann SJ, Schootman M, Schoenecker PL, Dobbs MB, Gordon JE (2004) Complications and Outcomes of Open Pediatric Forearm Fractures. J Pediatr Orthop 24:1-6

126. Capo JT, Hall M, Nourbakhsh A, Tan V, Henry P (2011) Initial management of open hand fractures in an emergency department. Am J Orthop 40:E243-248

127. Kreder HJ, Armstrong P (1994) The significance of perioperative cultures in open pediatric lowerextremity fractures. Clin Orthop:206-212

128. Robinson D, On E, Hadas N, Halperin N, Hofman S, Boldur I (1989) Microbiologic flora contaminating open fractures: its significance in the choice of primary antibiotic agents and the likelihood of deep wound infection. J Orthop Trauma 3:283-286 
129. Seekamp A, Köntopp H, Schandelmaier P, Krettek C, Tscherne H (2000) Bacterial cultures and bacterial infections in open fractures. Eur J Trauma 26:131-138. DOI 10.1007/s000680050011

130. Valenziano CP, Chattar-Cora D, O'Neill A, Hubli EH, Cudjoe EA (2002) Efficacy of primary wound cultures in long bone open extremity fractures: Are they of any value? Arch Orthop Trauma Surg 122:259-261. DOI 10.1007/s00402-001-0363-6

131. Dellinger EP, Caplan ES, Weaver LD, Wertz MJ, Droppert BM, Hoyt N, Brumback R, Burgess A, Poka A, Benirschke SK, Lennard ES, Lou MA (1988) Duration of preventive antibiotic administration for open extremity fractures. Arch Surg 123:333-339

132. Saveli CC, Morgan SJ, Belknap RW, Ross E, Stahel PF, Chaus GW, Hak DJ, Biffl WL, Knepper B, Price CS (2013) Prophylactic antibiotics in open fractures: A pilot randomized clinical safety study. J Orthop Trauma 27:552-557. DOI 10.1097/BOT.0b013e31828d92ee

133. Ostermann PAW, Seligson D, Henry SL (1995) Local antibiotic therapy for severe open fractures. A review of 1085 consecutive cases. J Bone Joint Surg $\mathrm{Br}$ 77:93-97

134. Lenarz CJ, Watson JT, Moed BR, Israel H, Mullen JD, MacDonald JB (2010) Timing of wound closure in open fractures based on cultures obtained after debridement. J Bone Jt Surg Ser A 92:1921-1926. DOI 10.2106/jbjs.i.00547

135. Bednar DA, Parikh J (1993) Effect of time delay from injury to primary management on the incidence of deep infection after open fractures of the lower extremities caused by blunt trauma in adults. J Orthop Trauma 7:532-535

136. DeLong Jr WG, Born CT, Wei SY, Petrik ME, Ponzio R, Schwab CW (1999) Aggressive treatment of 119 open fracture wounds. J Trauma Inj Infect Crit Care 46:1049-1054. DOI 10.1097/00005373199906000-00012

137. Henry SL, Ostermann PAW, Seligson D (1990) The prophylactic use of antibiotic impregnated beads in open fractures. J TRAUMA 30:1231-1238

138. Torchia ME, Lewallen DG (1996) Open fractures of the patella. J Orthop Trauma 10:403-409

139. Kakar S, Tornetta IP (2007) Open fractures of the tibia treated by immediate intramedullary tibial nail insertion without reaming: A prospective study. J Orthop Trauma 21:153-157. DOI 10.1097/BOT.0b013e3180336923

140. Sanders R, Jersinovich I, Anglen J, Dipasquale T, Herscovici D (1994) The Treatment of Open Tibial Shaft Fractures Using an Interlocked Intramedullary Nail without Reaming. Journal of Orthopaedic Trauma 8:504-510

141. Henley MB, Chapman JR, Agel J, Harvey EJ, Whorton AM, Swiontkowski MF (1998) Treatment of type II, IIIA, and IIIB open fractures of the tibial shaft: a prospective comparison of unreamed interlocking intramedullary nails and half-pin external fixators. J Orthop Trauma 12:1-7

142. Keating JF, Blachut PA, O'Brien PJ, Meek RN, Broekhuyse H (1996) Reamed nailing of open tibial fractures: does the antibiotic bead pouch reduce the deep infection rate? J Orthop Trauma 10:298-303

143. Keating JF, O'Brien PJ, Blachut PA, Meek RN, Broekhuyse HM (1997) Locking intramedullary nailing with and without reaming for open fractures of the tibial shaft. A prospective randomized study. J Bone Joint Surg Am 79:334-341

144. Chua W, Murphy D, Siow W, Kagda F, Thambiah J (2012) Epidemiological analysis of outcomes in 323 open tibial diaphyseal fractures: A nine-year experience. Singapore Med J 53:385-389

145. Hope PG, Cole WG (1992) Open fractures of the tibia in children. J Bone Joint Surg Br 74:546-553

146. Irwin A, Gibson P, Ashcroft P (1995) Open fractures of the tibia in children. Injury 26:21-24. DOI 10.1016/0020-1383(95)90547-b

147. Jenny JY, Jenny G, Gaudias J (1995) The risk of post-operative infection after reamed intramedullary locked nailing of tibial fractures. A review of 730 cases. Eur $j$ orthop surg traumatol 5:79-82

148. Joshi D, Ahmed A, Krishna L, Lal Y (2004) Unreamed interlocking nailing in open fractures of tibia. J Orthop Surg (Hong Kong) 12:216-221 
149. Rao P, Schaverien MV, Stewart KJ (2010) Soft tissue management of children's open tibial fractures-a review of seventy children over twenty years. Ann R Coll Surg Engl 92:320-325. DOI $10.1308 / 003588410 \times 12664192075017$

150. Sungaran J, Harris I, Mourad M (2007) The effect of time to theatre on infection rate for open tibia fractures. ANZ J Surg 77:886-888. DOI 10.1111/j.1445-2197.2007.04266.x

151. Siwach R, Singh R, Arya S, Gupta R (2007) Treatment of 78 type II and type Illa open fractures by primary closure on suction drain: A prospective study. J Orthop Traumatol 8:173-176. DOI 10.1007/s10195-007-0085-9

152. Usman UI Haq M, Hussain FN, Iqbal M (2014) Outcome of immediate primary skin closure in type-II and type-IIIA open tibial fractures. Rawal Med J 39:285-288

153. Wani N, Baba A, Kangoo K, Mir M (2011) Role of early llizarov ring fixator in the definitive management of type II, IIIA and IIIB open tibial shaft fractures. Int Orthop 35:915-923. DOI 10.1007/s00264-010-1023-7

154. Chandra CP, Rao KCS, Reddy AK, Srinivas B (2016) A Study on Internal Fixation of Compound Fractures of Tibia Using Interlocking Nail without Reaming. Journal of Evolution of Medical and Dental Sciences-Jemds 5:2897-2900

155. Huang Z, Wang B, Chen F, Huang J, Jian G, Gong H, Xu T, Chen R, Chen X, Ye Z, Wang J, Xie D, Liu H (2015) Fast pinless external fixation for open tibial fractures: Preliminary report of a prospective study. Int J Clin Exp Med 8:20805-20812

156. Kumar KH (2015) A Study of the Management of Open Fractures of Tibia by Unreamed Interlocking Nail. Journal of Evolution of Medical and Dental Sciences-Jemds 4:12428-12446

157. Momaya AM, Hlavacek J, Etier B, Johannesmeyer D, Oladeji LO, Niemeier TE, Herrera N, Lowe JA (2016) Risk factors for infection after operative fixation of Tibial plateau fractures. Injury 47:1501-1505

158. Ren T, Ding L, Xue F, He Z, Xiao H (2015) Risk factors for surgical site infection of pilon fractures. Clinics 70:419-422

159. Zhang $X$, Liu $Y$, Peng A, Wang $H$, Zhang $Y$ (2015) Clinical efficacy and prognosis factors of open calcaneal fracture: A retrospective study. Int J Clin Exp Med 8:3841-3847

160. Fernandes Mde C, Peres LR, de Queiroz AC, Jr., Lima JQ, Jr., Turibio FM, Matsumoto MH (2015) Open fractures and the incidence of infection in the surgical debridement 6 hours after trauma. Acta ortop bras 23:38-42

161. Sagi HC, Cooper S, Donahue D, Marberry S, Steverson B (2015) Seasonal variations in posttraumatic wound infections after open extremity fractures. J Trauma Acute Care Surg 79:1073-1078

162. Leonidou A, Kiraly Z, Gality H, Apperley S, Vanstone S, Woods DA (2014) The effect of the timing of antibiotics and surgical treatment on infection rates in open long-bone fractures: a 6-year prospective study after a change in policy. Strategies Trauma Limb Reconstr 9:167-171

163. Stevenson J, McNaughton G, Riley J (2003) The use of prophylactic flucoxacillin in treatment of open fractures of the distal phalanx within an accident and emergency department: A double-blind randomized placebo-controlled trial. J Hand Surg (GBR) 28 B:388-394. DOI 10.1016/s02667681(03)00175-x

164. Srour M, Inaba K, Okoye O, Chan C, Skiada D, Schnuriger B, Trump M, Lam L, Demetriades D (2015) Prospective Evaluation of Treatment of Open Fractures: Effect of Time to Irrigation and Debridement. JAMA Surg 150:332-336

165. Wei SJ, Cai XH, Wang HS, Qi BW, Yu AX (2014) A comparison of primary and delayed wound closure in severe open tibial fractures initially treated with internal fixation and vacuum-assisted wound coverage: A case-controlled study. Int J Surg 12:688-694. DOI 10.1016/j.ijsu.2014.04.010

166. Singh J, Rambani R, Hashim Z, Raman R, Sharma HK (2012) The relationship between time to surgical debridement and incidence of infection in grade III open fractures. Strategies Trauma Limb Reconstr 7:33-37 
167. Angly B, Constantinescu MA, Kreutziger J, Juon BH, Vogelin E (2012) Early versus Delayed Surgical Treatment in Open Hand Injuries: A Paradigm Revisited. World Journal of Surgery 36:826-829

168. Al-Hilli AB, Salih DS (2010) Early or delayed surgical treatment in compound limb fractures due to high velocity missile injuries: a 5-year retrospective study from Medical City in Baghdad. lowa Orthop J 30:94-98

169. Gupta A, Bijyal A, Raina P, Singh M (2015) Early Verses Delayed Primary Interlocking Nailing in Compound 3b Tibia Fractures: A Study of 100 Cases. Journal of Evolution of Medical and Dental Sciences-Jemds 4:14493-14496

170. Pollak AN, Jones AL, Castillo RC, Bosse MJ, MacKenzie EJ (2010) The relationship between time to surgical débridement and incidence of infection after open high-energy lower extremity trauma. J Bone Jt Surg Ser A 92:7-15. DOI 10.2106/jbjs.h.00984

171. Swiontkowski MF (1989) Criteria for bone debridement in massive lower limb trauma. Clin Orthop:41-47

172. Yokoyama K, Itoman M, Shindo M, Kai H (1995) Contributing factors influencing type III open tibial fractures. J Trauma 38:788-793. DOI 10.1097/00005373-199505000-00019

173. Gopal S, Majumder S, Batchelor AGB, Knight SL, De Boer P, Smith RM (2000) Fix and flap: The radical orthopaedic and plastic treatment of severe open fractures of the tibia. J Bone Jt Surg Ser B 82:959-966

174. Bali K, Aggarwal S, Kumar V, Mootha AK, Rawall S, Tahasildar N, Dhillon MS (2011) Operative management of type II and type IIla open tibial fractures presenting from 6-24 hours after injury: An Indian experience. Curr Orthop Pract 22:262-266. DOI 10.1097/BCO.0b013e31821374ba

175. Rodrigues FL, De Abreu LC, Valenti VE, Valente AL, Da Costa Pereira Cestari R, Pohl PHI, Rodrigues LMR (2014) Bone tissue repair in patients with open diaphyseal tibial fracture treated with biplanar external fixation or reamed locked intramedullary nailing. Injury 45:S32-S35. DOI 10.1016/s00201383(14)70018-x

176. Mathews JA, Ward J, Chapman TW, Khan UM, Kelly MB (2015) Single-stage orthoplastic reconstruction of Gustilo-Anderson Grade III open tibial fractures greatly reduces infection rates. Injury 46:2263-2266

177. Sterett WI, Ertl JP, Chapman MW, Moehring HD (1995) Open tibia fractures in the splenectomized trauma patient: results of treatment with locking, intramedullary fixation. J Trauma 38:639-641

178. Cordero-Ampuero J, de Dios M (2010) What are the risk factors for infection in hemiarthroplasties and total hip arthroplasties? Clin Orthop Relat Res 468:3268-3277. DOI 10.1007/s11999-010-1411-8

179. Harris AH, Reeder R, Ellerbe L, Bradley KA, Rubinsky AD, Giori NJ (2011) Preoperative alcohol screening scores: association with complications in men undergoing total joint arthroplasty. J Bone Joint Surg Am 93:321-327. DOI 93/4/321 [pii]

10.2106/JBJS.I.01560

180. Lehman CR, Ries MD, Paiement GD, Davidson AB (2001) Infection after total joint arthroplasty in patients with human immunodeficiency virus or intravenous drug use. J Arthroplasty 16:330-335. DOI S0883-5403(01)68146-4 [pii]

10.1054/arth.2001.21454

181. Habermann B, Eberhardt C, Kurth AA (2008) Total joint replacement in HIV positive patients. J Infect 57:41-46. DOI S0163-4453(08)00065-0 [pii]

10.1016/j.jinf.2008.01.045

182. Lieberman JR, Fuchs MD, Haas SB, Garvin KL, Goldstock L, Gupta R, Pellicci PM, Salvati EA (1995) Hip arthroplasty in patients with chronic renal failure. J Arthroplasty 10:191-195. DOI S0883-5403(05)801263 [pii] 
183. Sakalkale DP, Hozack WJ, Rothman RH (1999) Total hip arthroplasty in patients on long-term renal dialysis. J Arthroplasty 14:571-575. DOI S0883-5403(99)90079-7 [pii]

184. Pour AE, Matar WY, Jafari SM, Purtill JJ, Austin MS, Parvizi J (2011) Total joint arthroplasty in patients with hepatitis C. J Bone Joint Surg Am 93:1448-1454. DOI 10.2106/JBJS.J.00219

185. Hsieh PH, Chen LH, Lee MS, Chen CH, Yang WE, Shih CH (2003) Hip arthroplasty in patients with cirrhosis of the liver. J Bone Joint Surg Br 85:818-821

186. Gosselin RA, Roberts I, Gillespie WJ (2004) Antibiotics for preventing infection in open limb fractures. Cochrane Database Syst Rev 1:CD003764. DOI 10.1002/14651858.CD003764.pub2 
Table 1. Possible risk factors for the development of postoperative infectious complications in open fractures.

Percentages between parentheses unless otherwise specified

\begin{tabular}{|c|c|c|c|c|c|c|c|}
\hline Factor & $\begin{array}{l}\text { No of } \\
\text { articles }\end{array}$ & $\begin{array}{l}\text { No of } \\
\text { patients }\end{array}$ & Not infected & Infected & Heterogeneity & & Outcome \\
\hline \multicolumn{5}{|c|}{ Patient-Related Risk Factors } & $\mathrm{Chi}^{2}$ (p-value) & $I^{2}(\%)$ & $\mathrm{RR}, 95 \% \mathrm{Cl}$ \\
\hline Age (mean, SD) & 10 & 1,819 & $40.3(17.0)$ & $41.4(16.4)$ & $6.69(0.46)$ & 0 & $1.48-0.63-3.58^{a}$ \\
\hline BMI (mean, SD) & 2 & 306 & $27.3(5.5)$ & $26.4(6.6)$ & $0.02(0.88)$ & 0 & $0.76,-0.85-2.36^{a}$ \\
\hline Male & \multirow{2}{*}{13} & 1,485 & $1,246(84)$ & $239(16)$ & $11.25(0.51)$ & 0 & $1.42,1.12-1.80$ \\
\hline Female & & 681 & $602(88)$ & $79(12)$ & & & \\
\hline Caucasian & \multirow[t]{2}{*}{1} & 123 & $92(75)$ & $31(25)$ & NA & NA & $2.39,0.62-9.20$ \\
\hline Non Caucasian & & 19 & $17(89)$ & $2(11)$ & & & \\
\hline ASA-score $>2$ & \multirow{2}{*}{1} & 80 & $64(80)$ & $16(20)$ & NA & NA & $3.00,0.73-12.27$ \\
\hline ASA-score $<2$ & & 30 & $28(93)$ & $2(7)$ & & & \\
\hline DM & \multirow[t]{2}{*}{5} & 79 & $59(75)$ & $20(25)$ & $1.27(0.87)$ & 0 & $1.72,1.14-2.61$ \\
\hline No DM & & 845 & $728(86)$ & $117(14)$ & & & \\
\hline HIV + & \multirow[t]{2}{*}{2} & 61 & $53(87)$ & $8(13)$ & $0.28(0.60)$ & 0 & $0.71,0.35-1.45$ \\
\hline HIV - & & 143 & $113(79)$ & $30(21)$ & & & \\
\hline Vascular disease & \multirow[t]{2}{*}{2} & 134 & $105(78)$ & $29(22)$ & $3.24(0.07)$ & 69 & $1.60,0.97-2.63$ \\
\hline No vascular disease & & 118 & $96(81)$ & $22(17)$ & & & \\
\hline Smoking & \multirow{2}{*}{11} & 594 & $489(82)$ & $105(18)$ & $4.26(0.89)$ & 0 & $1.29,1.02-1.64$ \\
\hline No smoking & & 1,131 & 975 (86) & $156(14)$ & & & \\
\hline Alcohol $^{b}$ & \multirow{2}{*}{3} & 225 & $182(81)$ & $43(19)$ & $1.45(0.48)$ & 0 & $1.39,0.93-2.07$ \\
\hline No alcoholb & & 290 & $250(86)$ & $40(14)$ & & & \\
\hline Drugs $^{b}$ & \multirow{2}{*}{2} & 97 & $78(80)$ & $19(20)$ & $0.42(0.52)$ & 0 & $1.33,0.82-2.17$ \\
\hline No drugs ${ }^{b}$ & & 308 & $262(85)$ & $46(15)$ & & & \\
\hline \multicolumn{8}{|c|}{ Fracture Related Risk Factors } \\
\hline Upper extremityc & 20 & 1,799 & $1,701(95)$ & $98(5)$ & $34.09(0.02)$ & $44^{d}$ & $0.51,0.38-0.70$ \\
\hline
\end{tabular}




\begin{tabular}{|c|c|c|c|c|c|c|c|}
\hline Clavicle & 2 & 2 & $2(100)$ & 0 & $0.12(0.72)$ & 0 & $6.18,1.02-37.45$ \\
\hline Humerus & 11 & 166 & $157(95)$ & $9(5)$ & $6.76(0.75)$ & 0 & $0.98,0.57-1.69$ \\
\hline Elbow & 3 & 53 & $51(96)$ & $2(4)$ & $4.92(0.09)$ & $59^{d}$ & $0.87,0.12-6.44$ \\
\hline Forearm & 11 & 554 & $529(95)$ & $25(5)$ & $13.09(0.22)$ & 24 & $0.69,0.42-1.13$ \\
\hline Hand & 4 & 71 & $69(97)$ & $2(3)$ & $18.16(<0.001)$ & $83^{d}$ & $3.56,0.48-26.59$ \\
\hline Lower extremityc & 20 & 4,146 & $3,657(88)$ & $489(12)$ & $34.09(0.02)$ & $44^{d}$ & $1.94,1.42-2.66$ \\
\hline Femur & 21 & 744 & $644(87)$ & $100(13)$ & $9.07(0.34)$ & 12 & $0.91,0.55-1.52$ \\
\hline Tibia & 21 & 4,614 & $4,060(88)$ & $554(12)$ & $47.29(<0.001)$ & $58^{d}$ & $1.29,0.97-1.71$ \\
\hline Knee & 2 & 41 & $36(88)$ & $5(12)$ & $0.06(0.81)$ & 0 & $0.55,0.23-1.29$ \\
\hline Patella & 4 & 25 & $24(96)$ & $1(4)$ & $2.07(0.56)$ & 0 & $1.69,0.50-5.73$ \\
\hline Ankle & 9 & 179 & $142(79)$ & $37(21)$ & $6.22(0.51)$ & 0 & $1.42,0.97-2.08$ \\
\hline Calcaneus & 2 & 4 & $3(75)$ & $1(25)$ & $0.01(0.93)$ & 0 & $3.3,0.84-12.89$ \\
\hline Foot & 6 & 158 & $156(99)$ & $2(1)$ & $3.58(0.61)$ & 0 & $1.16,0.86-1.55$ \\
\hline Grade I & & 4,058 & $3,942(97)$ & $116(3)$ & & & \\
\hline Grade II & 84 & 4,888 & $4,548(93)$ & $340(7)$ & $159.35(<0.00001)$ & 47 & $3.01,2.55-3.55^{e}$ \\
\hline Grade III & & 6,338 & $5,332(84)$ & $1,006(16)$ & & & \\
\hline Contamination & 3 & 428 & $348(81)$ & $80(19)$ & $5.09(0.08)$ & $61^{\mathrm{d}}$ & $7.85,2.09-29.40$ \\
\hline No contamination & & 452 & $441(97.6)$ & $11(2.4)$ & & & \\
\hline \multicolumn{8}{|c|}{ Trauma Related Risk Factors } \\
\hline Motorcycle & $3[22,39$ & 157 & $127(81)$ & $30(19)$ & $0.76(0.68)$ & 0 & $1.40,0.92-2.15$ \\
\hline Automobile & 53] & 144 & $132(91.7)$ & $12(8.3)$ & $0.45(0.50)$ & 0 & $0.53,0.27-1.01$ \\
\hline Pedestrian & 2 & 185 & $155(84)$ & $30(16)$ & $13.86(0.001)$ & $86^{d}$ & $1.17,0.30-4.66$ \\
\hline Assault without & 3 & 10 & $10(100)$ & 0 & NA & NA & $0.38,0.02-5.74$ \\
\hline weapon & 1 & & & & & & \\
\hline Gunshot wound & & 51 & 49 (96.1) & $2(3.9)$ & $5.28(0.02)$ & $81^{d}$ & $0.44,0.01-16.63$ \\
\hline Fall from height & 2 & 19 & $13(68)$ & $6(32)$ & NA & NA & $3.16,1.48-6.75$ \\
\hline Farmyard injury & 1 & 2 & 0 & $2(100)$ & NA & NA & $7.22,2.64-19.74$ \\
\hline & 1 & & & & & & \\
\hline
\end{tabular}




\begin{tabular}{|c|c|c|c|c|c|c|c|}
\hline Polytrauma & \multirow{2}{*}{4} & 421 & $342(81)$ & $79(19)$ & \multirow[t]{2}{*}{$4.93(0.18)$} & \multirow[t]{2}{*}{39} & \multirow[t]{2}{*}{$1.49,1.05-2.13$} \\
\hline Monotrauma & & 320 & $282(88)$ & $38(12)$ & & & \\
\hline Higher ISS & \multirow{2}{*}{4} & 423 & $376(89)$ & $47(11)$ & \multirow[t]{2}{*}{$3.78(0.29)$} & \multirow[t]{2}{*}{21} & \multirow[t]{2}{*}{$0.86,0.61-1.20$} \\
\hline Lower ISS & & 706 & $616(87)$ & $90(13)$ & & & \\
\hline \multicolumn{8}{|c|}{ Treatment Related Risk Factors } \\
\hline$A B$ & \multirow{2}{*}{2} & 141 & $136(96.5)$ & $5(3.5)$ & \multirow[t]{2}{*}{$1.95(0.16)$} & \multirow[t]{2}{*}{$49^{d}$} & \multirow[t]{2}{*}{$0.35,0.08-1.47$} \\
\hline No $A B$ & & 139 & $123(88)$ & $16(12)$ & & & \\
\hline$A B>3 h r s$ & \multirow{2}{*}{3} & 335 & $302(90.1)$ & $33(9.9)$ & \multirow[t]{2}{*}{$0.44(0.80)$} & \multirow[t]{2}{*}{0} & \multirow[t]{2}{*}{$1.29,0.59-2.79$} \\
\hline$A B<3 h r s$ & & 92 & $85(92.4)$ & $7(7.6)$ & & & \\
\hline Debridement $>6 \mathrm{hrs}$ & \multirow[t]{2}{*}{21} & 2,111 & $1,867(88)$ & $244(12)$ & \multirow[t]{2}{*}{$26.95(0.14)$} & \multirow[t]{2}{*}{26} & \multirow[t]{2}{*}{$1.00,0.85-1.18$} \\
\hline Debridement $<6 \mathrm{hrs}$ & & 2,202 & $1,964(89)$ & $238(11)$ & & & \\
\hline External fixation & 17 & 550 & $420(76)$ & $130(24)$ & $77.63(<0.00001)$ & $79^{d}$ & $0.85,0.50-1.44$ \\
\hline Delayed wound closure & & 151 & $122(81)$ & $29(19)$ & \multirow[t]{2}{*}{$4.87(0.18)$} & \multirow[t]{2}{*}{38} & \multirow[t]{2}{*}{$0.90,0.52-1.56$} \\
\hline $\begin{array}{l}\text { Immediate wound } \\
\text { closure }\end{array}$ & 4 & 79 & $62(78)$ & $17(22)$ & & & \\
\hline Pulsatile lavage & \multirow{2}{*}{1} & 54 & $41(76)$ & $13(24)$ & \multirow[t]{2}{*}{ NA } & \multirow[t]{2}{*}{ NA } & \multirow[t]{2}{*}{$2.70,1.03-7.05$} \\
\hline No pulsatile lavage & & 56 & $51(91)$ & $5(8.9)$ & & & \\
\hline Blood transfusion & & 322 & $278(86)$ & $44(14)$ & \multirow[t]{3}{*}{$0.00(0.99)$} & \multirow[t]{3}{*}{0} & $2.08,1.39-3.12$ \\
\hline No blood & 2 & 650 & $610(93.8)$ & $40(6.2)$ & & & \\
\hline transfusion & & & & & & & \\
\hline Splenectomy & 1 & 8 & $6(75)$ & $2(25)$ & NA & NA & $5.38,0.88-32.81$ \\
\hline No splenectomy & & 43 & $41(95.3)$ & $2(4.7)$ & & & \\
\hline
\end{tabular}

RR, Risk Ratio; Cl, Confidence Interval; SD, Standard Deviation; BMI, Body Mass Index; ASA - American Society of Anesthesiologists; DM, Diabetes Mellitus; HIV, Human Immuno-deficiency Virus; NA, Not Applicable; ISS, Injury Severity Score; AB, Antibiotics

a. Provided value is mean difference instead of Risk Ratio 
b. As indicated by patients themselves, not measured at time of admission

c. Some articles did not specify individual bones, just upper versus lower extremity

d. Random effect model used

e. Grade III fractures are compared to grade I/II fractures combined

\section{Figure legends}

Figure 1 - Identified and final included articles during search and selection process
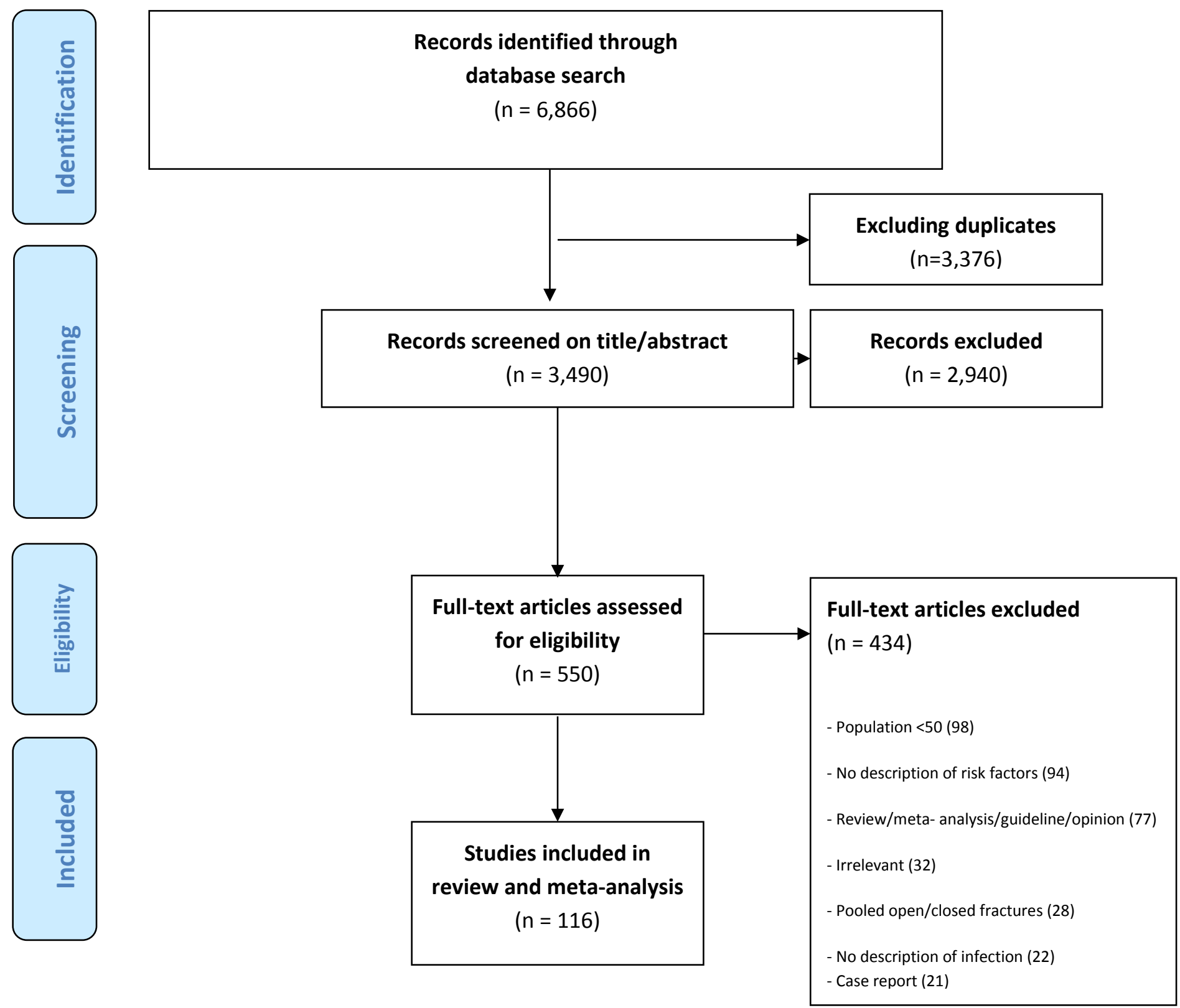
Figure 2 - Forest plot for infectious complications in male versus female patients with open fractures

\begin{tabular}{|c|c|c|c|c|c|c|c|c|c|c|c|c|}
\hline \multirow[b]{2}{*}{ Study or Subgroup } & \multicolumn{2}{|c|}{ Male } & \multicolumn{2}{|c|}{ Female } & \multicolumn{3}{|c|}{ Risk Ratio } & \multirow{2}{*}{\multicolumn{5}{|c|}{$\begin{array}{c}\text { Risk Ratio } \\
\text { M-H, Fixed, 95\% Cl }\end{array}$}} \\
\hline & Events & Total & Events & Total & Weight & M-H, Fixed, $95 \% \mathrm{Cl}$ & Year & & & & & \\
\hline Ovaska 2016 & 10 & 44 & 8 & 66 & $6.2 \%$ & $1.88[0.80,4.38]$ & 2016 & & & & & \\
\hline Lawing 2015 & 34 & 224 & 18 & 111 & $23.5 \%$ & $0.94[0.55,1.58]$ & 2015 & & & - & & \\
\hline Matos 2015 & 26 & 102 & 5 & 20 & $8.1 \%$ & $1.02[0.45,2.33]$ & 2015 & & & & & \\
\hline Molina 2015 & 24 & 83 & 9 & 59 & $10.3 \%$ & $1.90[0.95,3.78]$ & 2015 & & & & & \\
\hline Hull 2014 & 39 & 329 & 7 & 130 & $9.8 \%$ & $2.20[1.01,4.80]$ & 2014 & & & & & \\
\hline Chen 2013 & 12 & 114 & 8 & 88 & $8.8 \%$ & $1.16[0.49,2.71]$ & 2013 & & & & & \\
\hline Yusof 2013 & 17 & 52 & 0 & 6 & $0.9 \%$ & $4.62[0.31,68.67]$ & 2013 & & & & & \\
\hline Enninghorst 2011 & 11 & 66 & 4 & 23 & $5.8 \%$ & $0.96[0.34,2.71]$ & 2011 & & & & & \\
\hline Yokoyama 2009 & 28 & 252 & 4 & 66 & $6.2 \%$ & $1.83[0.67,5.04]$ & 2009 & & & & & \\
\hline Hohmann 2007 & 1 & 74 & 1 & 21 & $1.5 \%$ & $0.28[0.02,4.35]$ & 2007 & & & & & \\
\hline Ikem 2006 & 23 & 57 & 12 & 32 & $15.0 \%$ & $1.08[0.62,1.86]$ & 2006 & & & 一 & & \\
\hline Vainionpaa 1990 & 7 & 35 & 3 & 25 & $3.4 \%$ & $1.67[0.48,5.83]$ & 1990 & & & & & \\
\hline Braun 1987 & 7 & 53 & 0 & 34 & $0.6 \%$ & $9.72[0.57,164.90]$ & 1987 & & & & & \\
\hline Total $(95 \% \mathrm{Cl})$ & & 1485 & & 681 & $100.0 \%$ & $1.42[1.12,1.80]$ & & & & $\nabla$ & & \\
\hline Total events & 239 & & 79 & & & & & & & & & \\
\hline $\begin{array}{l}\text { Heterogeneity: } \mathrm{Chi}^{2}= \\
\text { Test for overall effect }\end{array}$ & $\begin{array}{l}11.25, \mathrm{df} \\
Z=2.90\end{array}$ & $\begin{array}{l}=12(\mathrm{P} \\
(\mathrm{P}=0.0\end{array}$ & $\begin{array}{l}=0.51) \text {; } \\
04)\end{array}$ & $\left.\right|^{2}=0 \%$ & & & & 0.01 & $\begin{array}{c}0.1 \\
\text { Favours [Male] }\end{array}$ & ${ }^{1}$ Favours & $\begin{array}{c}10 \\
\text { [Female] }\end{array}$ & $100^{\circ}$ \\
\hline
\end{tabular}

Figure 3 - Forest plot for infectious complications in patients with and without diabetes mellitus

\begin{tabular}{|c|c|c|c|c|c|c|c|c|c|c|c|}
\hline \multirow[b]{2}{*}{ Study or Subgroup } & \multicolumn{2}{|l|}{ DM } & \multicolumn{2}{|c|}{ No DM } & \multicolumn{3}{|c|}{ Risk Ratio } & \multirow{2}{*}{\multicolumn{4}{|c|}{$\begin{array}{c}\text { Risk Ratio } \\
\text { M-H, Fixed, } 95 \% \mathrm{Cl}\end{array}$}} \\
\hline & Events & Total & Events & Total & Weight & M-H, Fixed, $95 \% \mathrm{Cl}$ & Year & & & & \\
\hline Ovaska 2016 & 5 & 15 & 13 & 95 & $17.2 \%$ & $2.44[1.01,5.85]$ & 2016 & & & $\longrightarrow$ & \\
\hline Lawing 2015 & 5 & 17 & 47 & 318 & $23.1 \%$ & $1.99[0.91,4.35]$ & 2015 & & & $\longrightarrow$ & \\
\hline Lack 2015 & 2 & 10 & 22 & 127 & $15.5 \%$ & $1.15[0.32,4.22]$ & 2015 & & & & \\
\hline Molina 2015 & 7 & 21 & 26 & 121 & $37.2 \%$ & $1.55[0.77,3.11]$ & 2015 & & & + & \\
\hline Zumsteg 2014 & 1 & 16 & 9 & 184 & $7.0 \%$ & $1.28[0.17,9.46]$ & 2014 & & & & \\
\hline Total $(95 \% \mathrm{Cl})$ & & 79 & & 845 & $100.0 \%$ & $1.72[1.14,2.61]$ & & & & & \\
\hline Total events & 20 & & 117 & & & & & & & & \\
\hline $\begin{array}{l}\text { Heterogeneity: Chi }{ }^{2} \\
\text { Test for overall effec }\end{array}$ & $\begin{array}{l}1.27, \mathrm{df}= \\
Z=2.58\end{array}$ & $\begin{array}{l}4(P= \\
P=0.0\end{array}$ & $\begin{array}{l}0.87) ;\left.\right|^{2}= \\
10)\end{array}$ & $=0 \%$ & & & & 0.01 & $\begin{array}{l}0.1 \\
\text { Favours [DM] }\end{array}$ & $\begin{array}{cc}1 & 10 \\
\text { Favours [No DM] }\end{array}$ & 100 \\
\hline
\end{tabular}


Figure 4 - Forest plot for infectious complications in smoking versus non-smoking patients

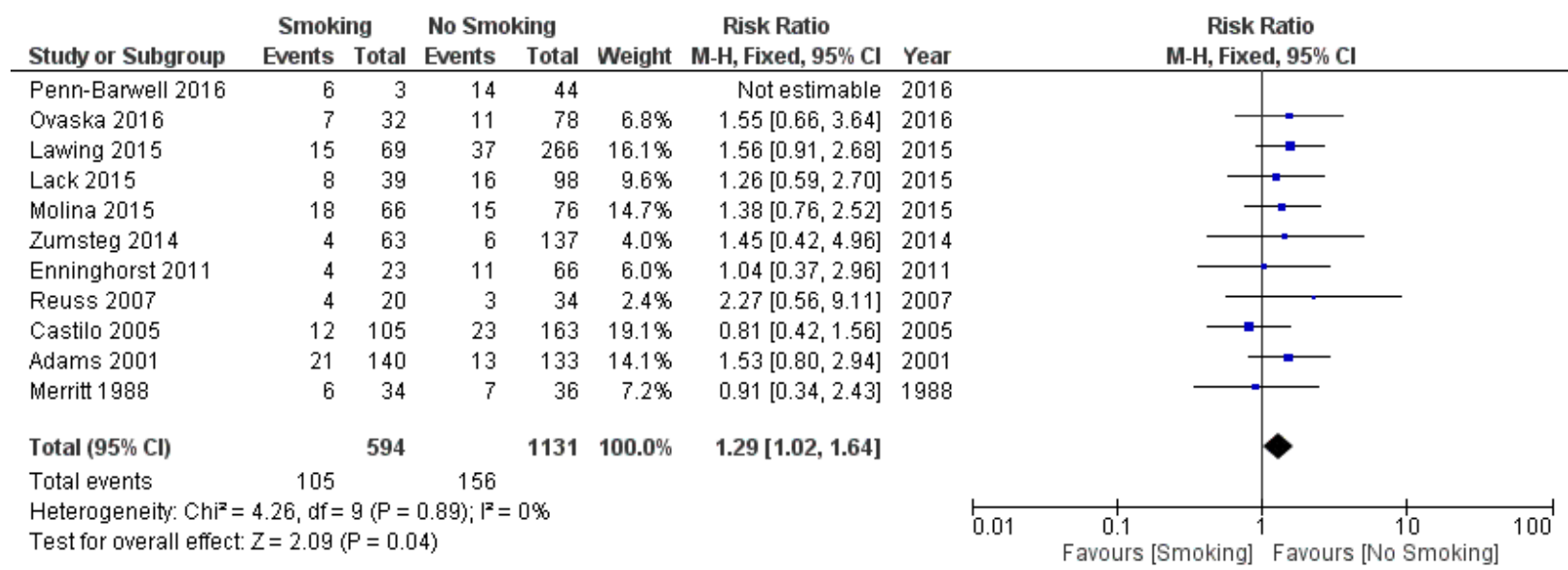

Figure 5 - Forest plot for infectious complications in patients with lower versus upper extremity fractures

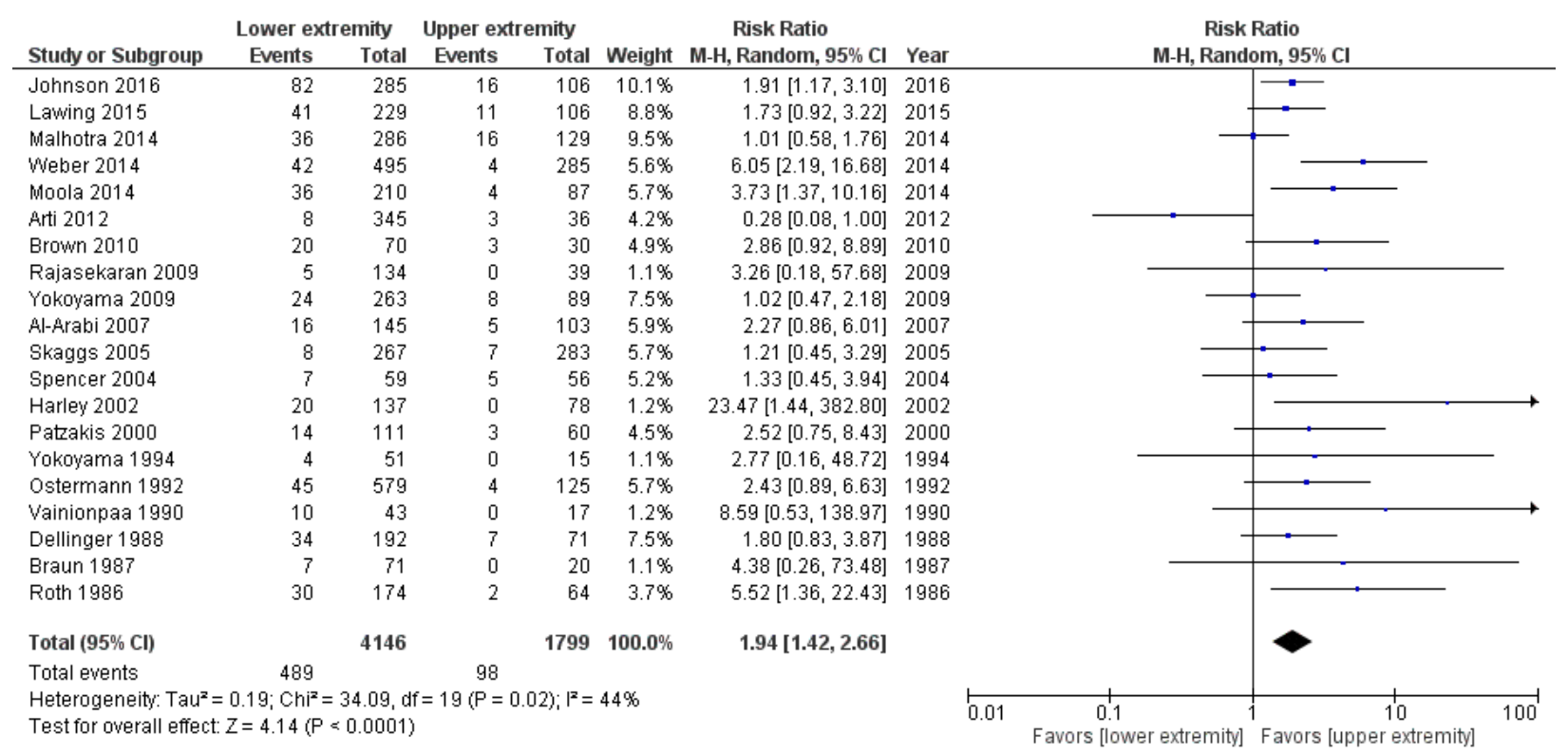


Figure 6 - Forest plot for infectious complications in patients with open versus closed fractures

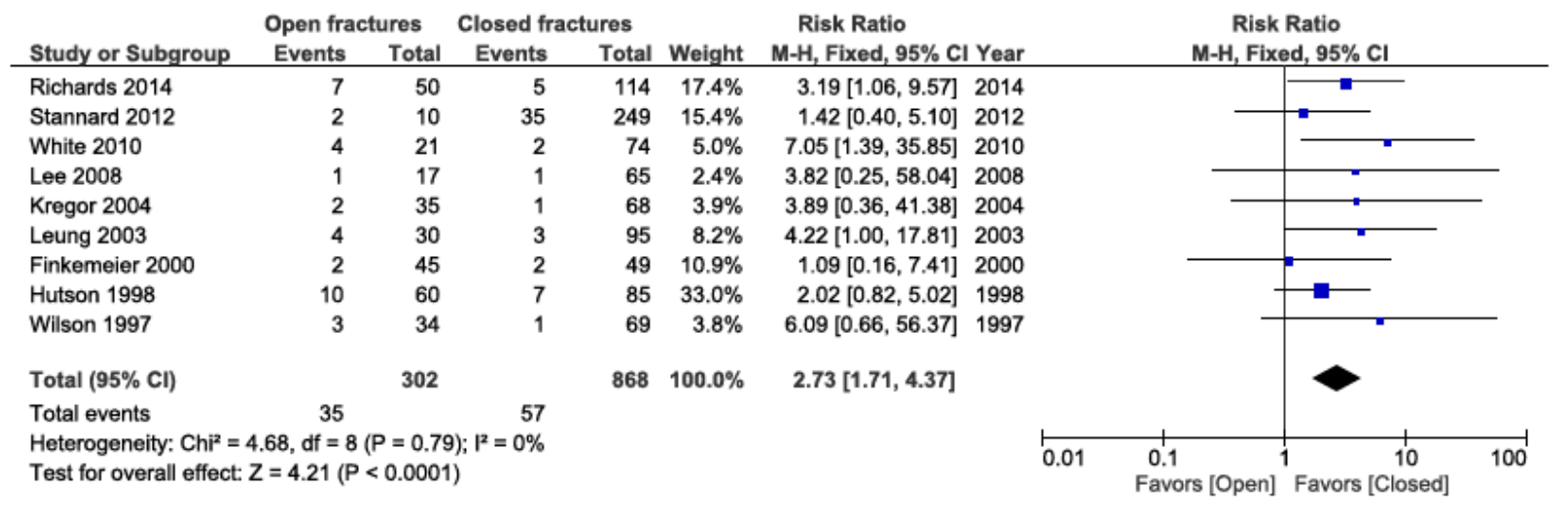

Figure 7 - Forest plot for infectious complications in patients with grade III versus grade I or II open fractures

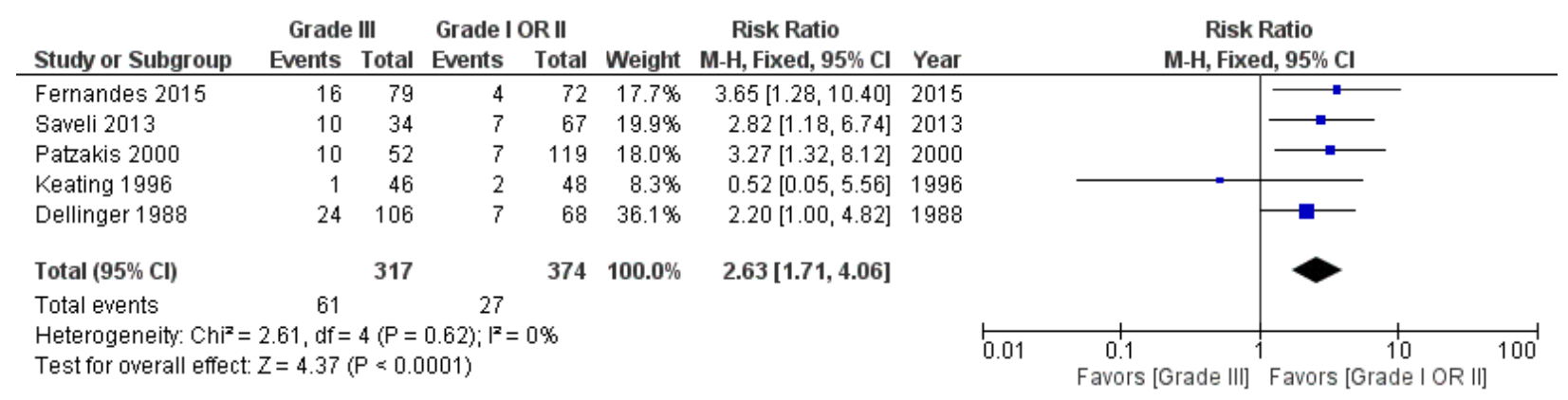

Figure 8 - Forest plot for infectious complications in patients with and without contamination of the wound

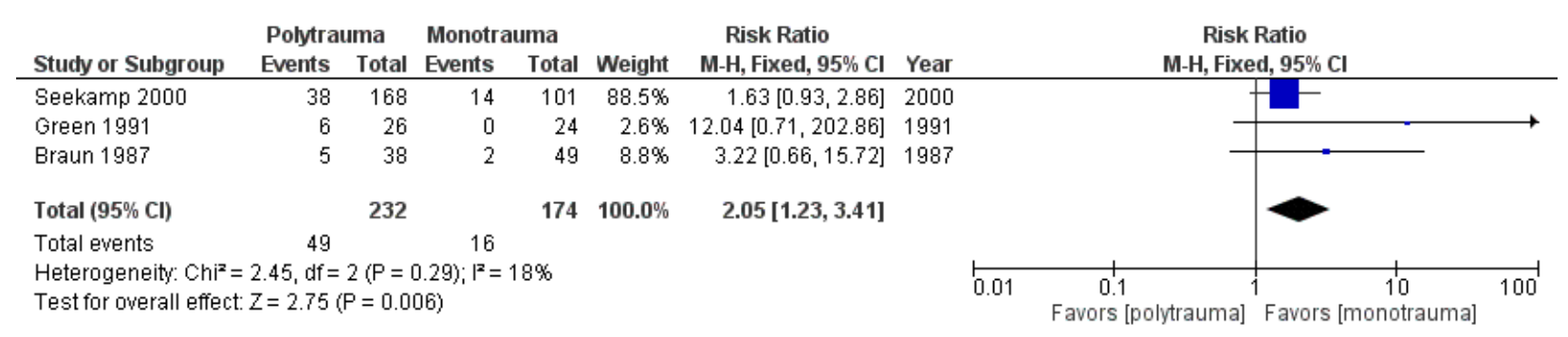


Figure 9 - Forest plot for infectious complications in polytrauma versus monotrauma patients with open fractures

\begin{tabular}{|c|c|c|c|c|c|c|c|c|c|c|c|c|}
\hline \multirow[b]{2}{*}{ Study or Subgroup } & \multicolumn{2}{|c|}{ Polytrauma } & \multicolumn{2}{|c|}{ Monotrauma } & \multicolumn{3}{|c|}{ Risk Ratio } & \multirow{2}{*}{\multicolumn{5}{|c|}{$\begin{array}{c}\text { Risk Ratio } \\
\text { M-H, Fixed, } 95 \% \mathrm{Cl}\end{array}$}} \\
\hline & Events & Total & Events & Total & Weight & M-H, Fixed, 95\% Cl & Year & & & & & \\
\hline Lawing 2015 & 30 & 189 & 22 & 146 & $55.7 \%$ & $1.05[0.64,1.75]$ & 2015 & & & & & \\
\hline Seekamp 2000 & 38 & 168 & 14 & 101 & $39.2 \%$ & $1.63[0.93,2.86]$ & 2000 & & & 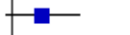 & & \\
\hline Green 1991 & 6 & 26 & 0 & 24 & $1.2 \%$ & $12.04[0.71,202.86]$ & 1991 & & & & & \\
\hline Braun 1987 & 5 & 38 & 2 & 49 & $3.9 \%$ & $3.22[0.66,15.72]$ & 1987 & & & & & \\
\hline Total $(95 \% \mathrm{Cl})$ & & 421 & & 320 & $100.0 \%$ & $1.49[1.05,2.13]$ & & & & & & \\
\hline Total events & 79 & & 38 & & & & & & & & & \\
\hline $\begin{array}{l}\text { Heterogeneity: } \mathrm{Chi}^{2} \\
\text { Test for overall effec }\end{array}$ & $\begin{array}{l}4.93, \mathrm{df}= \\
Z=2.21(\end{array}$ & $\begin{array}{l}3(P=0 \\
P=0.0\end{array}$ & 3) & & & & & 0.01 & $\begin{array}{c}0.1 \\
\text { Favors [polytrauma] }\end{array}$ & Favors [mo & $\begin{array}{c}10 \\
\text { onotrauma] }\end{array}$ & $100^{\circ}$ \\
\hline
\end{tabular}

Figure 10 - Forest plot for infectious complications in patients with and without a blood transfusion

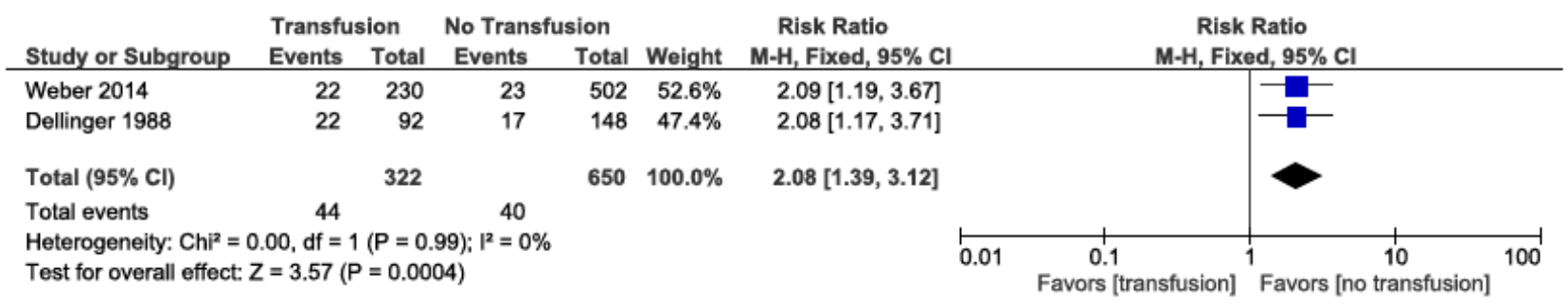

